\title{
Debreceni Egyetem
}

\author{
Informatika Kar
}

\section{Windows Communication Foundation}

Témavezető:

Dr. Fazekas Gábor

egyetemi docens
Készítette:

Szeifert Péter

programtervező

matematikus

Debrecen

2009 


\section{Tartalomjegyzék}

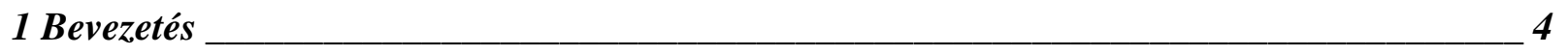

2 Végpontok _ 8

2.1 A végpont címe (address) ___ 9

2.2 Binding __ 12

2.3 Service contract ___ 13

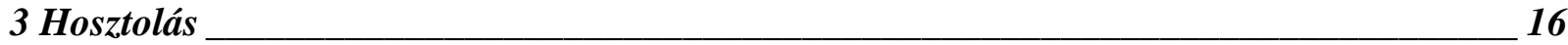

3.1 Self-hosting _ 16

3.2 Windows Process Activation Service (WAS) _ 17

4 Üzenetváltási modellek _____ 19

4.1 Kérés/válasz alapú üzenetváltás ____ 19

4.2 Egyirányú üzenetküldés ___ 20

4.3 Duplex modell___ 21

5 Szerializáció ___ 25

5.1 DataContractSerializer ___ 25

5.2 XmISerializer ___ 29

5.3 Message Contract____ 30

6 Aszinkron programozási modell (APM) __

6.1 Wait-Until-Done modell ___ 34

6.2 Polling modell____ 34

6.3 Callback modell ____ 35

6.4 Kivételkezelés aszinkron esetben ___ 36

6.5 Szinkron és aszinkron WCF metódusok ___ 37

7 Munkamenetek_______ 41

8 Szolgáltatás példányok ______ 44

9 Tranzakciók _______________ 47

10 Kivételkezelés ___

11 Diagnosztikai eszközök______________ 55

11.1 Teljesítményszámlálók ___ 55

11.2 Nyomkövetés_____ 57

$12 \mathrm{WCF}$ éS MSMQ 60 
13 Összefoglalás 67

14 Köszönetnyilvánitás 68

15 Irodalomjegyzék 69 


\section{Bevezetés}

A Windows Communication Foundation (WCF) egy egyesített, kiterjeszthető keretrendszer, amely biztonságos, megbízható, menedzselhető, más technológiákkal együttműködő alkalmazások írásában nyújt segítséget, a ma igényeinek eleget téve.

Míg más elosztott technológiák jól müködnek egy bizonyos környezetben, addig a Windows Communication Foundation minden esetben a legjobb megoldást kínálja. Például egy komplex alkalmazásnál felmerülhet az igény egy J2EE alkalmazással való kommunikációra, amelyre az ASP.NET web service megoldást jelenthet, de ha már Windows alapú alkalmazásra történő garantált kézbesítésre van szükség, akkor a Microsoft Message Queuing megoldása elengedhetetlen. A WCF esetében egyesítve megtaláljuk az alábbi technológiákat:

- ASMX

- WSE

- Enterprise Services

- System.Messaging

- .NET Remoting

- MSMQ

A Windows Communication Foundation tervezése során az alábbi célokat tűzték ki:

- A meglévő technológiák egyesítése

- Együttmüködés más platformokkal

- Szolgáltatás orientált fejlesztés

A különböző platformokon futtatott alkalmazások közötti kommunikációt nehezíti, hogy az adott gyártó által használt protokollok és a platform szorosan összefügg. A modern elosztott enterprise rendszereknél sokszor elkerülhetetlen a különböző technológiák, platformok összekapcsolása, ezért megszületett egy egységesített webszolgáltatás specifikáció. Mivel a webszolgáltatások 
nyílt szabványokat használnak, ezért lényegtelen, hogy az adott szolgáltatást milyen technológia felhasználásával írták. A WCF a SOAP üzenetküldési protokollt használja arra, hogy a kommunikációt megvalósítsa a heterogén rendszerekben.

Régebben az elosztott rendszereket olyan technológiák alkalmazásával fejlesztették, amelyek az objektum orientált paradigmára épültek, de szükség volt platformfüggetlen technológiákra. A technológia gyorsan változik, ezért a SOA (Service-oriented architecture) használatával egy alkalmazás képes lesz együttmüködni más platformokkal, türni a változásokat és kevesebb karbantartásra szorul. Az objektum orientált szemlélet a homogén rendszereket célozza, interfészek és osztályok megosztásán alapszik, míg a SOA mind a homogén, mind a heterogén rendszereket segíti és séma, illetve contract megosztással egy absztraktabb, kényelmesebb utat mutat.

A webszolgáltatások olyan széles körben elfogadott és alkalmazott szabványokra épülnek, mint az SOAP, XML, HTTP. Az XML webszolgáltatások könnyedén elérhetőek nem Windows platformról is.

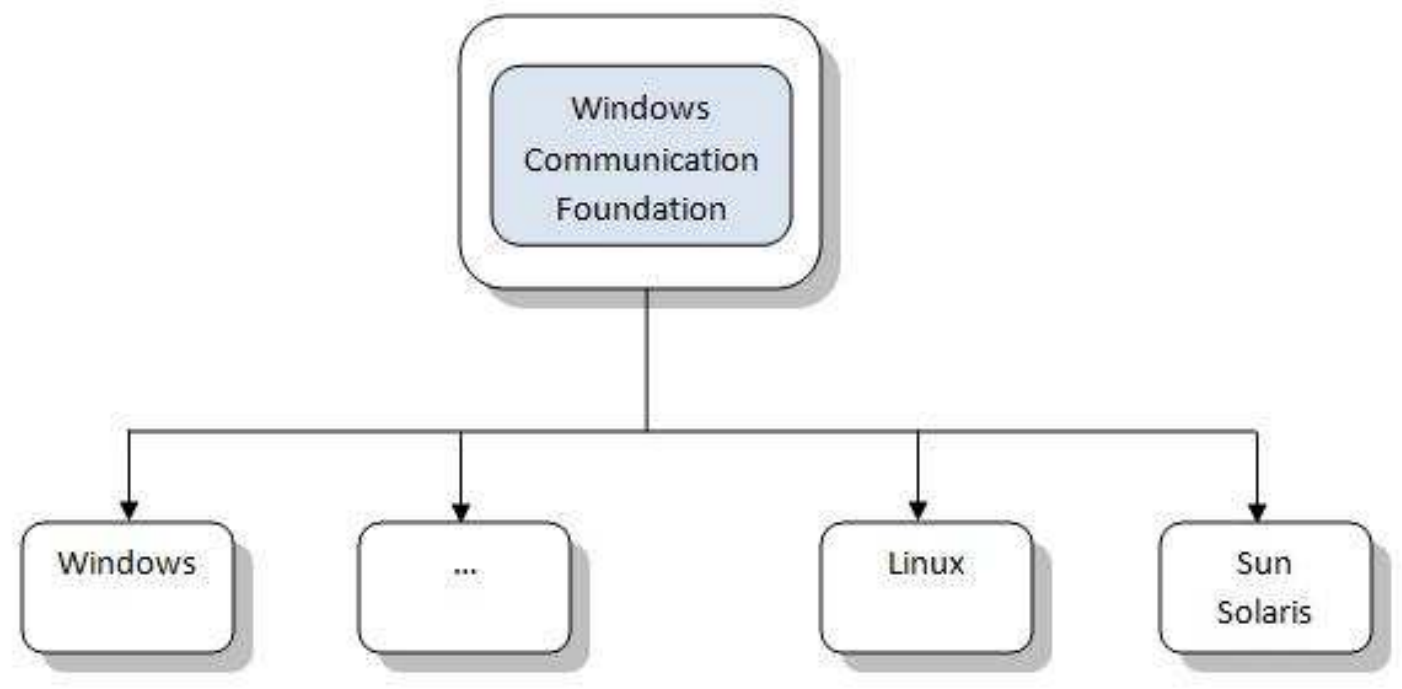

1. ábra - Együttmüködés más operációs rendszerekkel 
A szolgáltatás és a kliens független egymástól, azaz megállapodnak egy interfészben, amelyen keresztül kommunikálnak, de ezen felül mindegy a platform, az operációs rendszer.

A SOA szemszögéből egy szolgáltatás az alábbi alapelvekre épül:

- Explicit határok

Olyan belépési pontként funkcionáló publikus interfészt kell definiálni, amelyen keresztül megvalósulhat a kommunikáció. Ez az interfész ne legyen nagy, illetve ne tegyen közzé belső implementációs információkat. A megvalósított algoritmus absztrakciójaként funkcionál.

- Autonomitás

A szolgáltatások lazán csatoltak. Tudnak egymásról, de függetlenek maradnak.

- Séma és contract megosztása osztályok helyett.

Ez elősegíti a különböző technológiák közötti kommunikációt.

- Rendszabályok segítségével szétválasztható a szerkezeti és szemantikai kompatibilitás.

A WCF-ben, mint a .NET keretrendszerben általában, a következő programozási módszerek használhatók:

- Imperatív módon, kódban

- Konfigurációs fájlokon keresztül

- Deklaratív módon, attribútumokkal

Egy szolgáltatás írásánál általában párhuzamosan használjuk ezeket a modelleket, szem előtt tartva az egyes modellek előnyeit.

A WCF magában foglal számos meglévő elosztott technológiát, de ki is terjeszti azokat. A WCF deklaratív és imperatív programozási modellje segítségével kevesebb kód írásával is elérhetjük ugyanazt az eredményt, mint annak előtte. Konfigurációs fájlok használatával a szolgáltatás 
anélkül módosítható, hogy újra kellene azt fordítani, illetve a szerverre kihelyezni. Az attribútum alapú modellje pedig lehetőséget biztosít az üzleti logika és az üzenetküldést végző infrastruktúra szétválasztására.

Diplomamunkám célja a Windows Communication Foundation szolgáltatások írásához szükséges fogalmak és használatuk bemutatása, az általam fontosnak tartott technológiai lehetőségek (például aszinkron müködés, tranzakciós tulajdonság) ismertetése. 


\section{Végpontok}

A WCF szolgáltatással történő mindennemű kommunikáció végpontokon keresztül történik, ezeken keresztül érheti el a kliens a szolgáltatás müveleteit. Egy végpontot a következő négy tulajdonságával adhatjuk meg:

\section{- Address}

Cím, amely egyedileg azonosítja a végpontot és információt ad arról, hogy hol található a szolgáltatás.

- Binding

Meghatározza, hogy a kliens és a szolgáltatás hogyan kommunikálnak egymással (milyen protokollon keresztül, milyen kódolással, stb.).

- Contract

Meghatározza a szolgáltatás által publikált müveleteket, az adatok, üzenetek szerkezetét, az üzenetváltás irányát. A contract szó szerződést jelent, azaz egy megállapodás a kliens és a szolgáltatás között arról, hogy milyen szabályok szerint kommunikálnak egymással.

- Behaviors

A végpont viselkedését írja elő.

Az első három tulajdonságot kötelező megadni. Ezeket a WCF ábécéjének is szokták nevezni. Ezt a három tulajdonságot ismernie kell a kliensnek, ha használni akarja a szolgáltatást. A Web Service Description Language (WSDL) egy standard eszköz arra, hogy ezen adatokat publikálni lehessen, és más platformok is megértsék. Azt adja meg, hogy a szolgáltatás hol található, hogyan férhetünk hozzá, illetve milyen műveleteket támogat.

A végpontokat megadhatjuk imperatív módon a kódban, illetve deklaratív módon, konfigurációs fájlok használatával. Egy WCF szolgáltatás több végponttal is rendelkezhet, ezáltal az egyes végpontok a fentebb említett tulajdonságaikban eltérhetnek. Például más protokollon keresztül kommunikálhat a klienssel. 


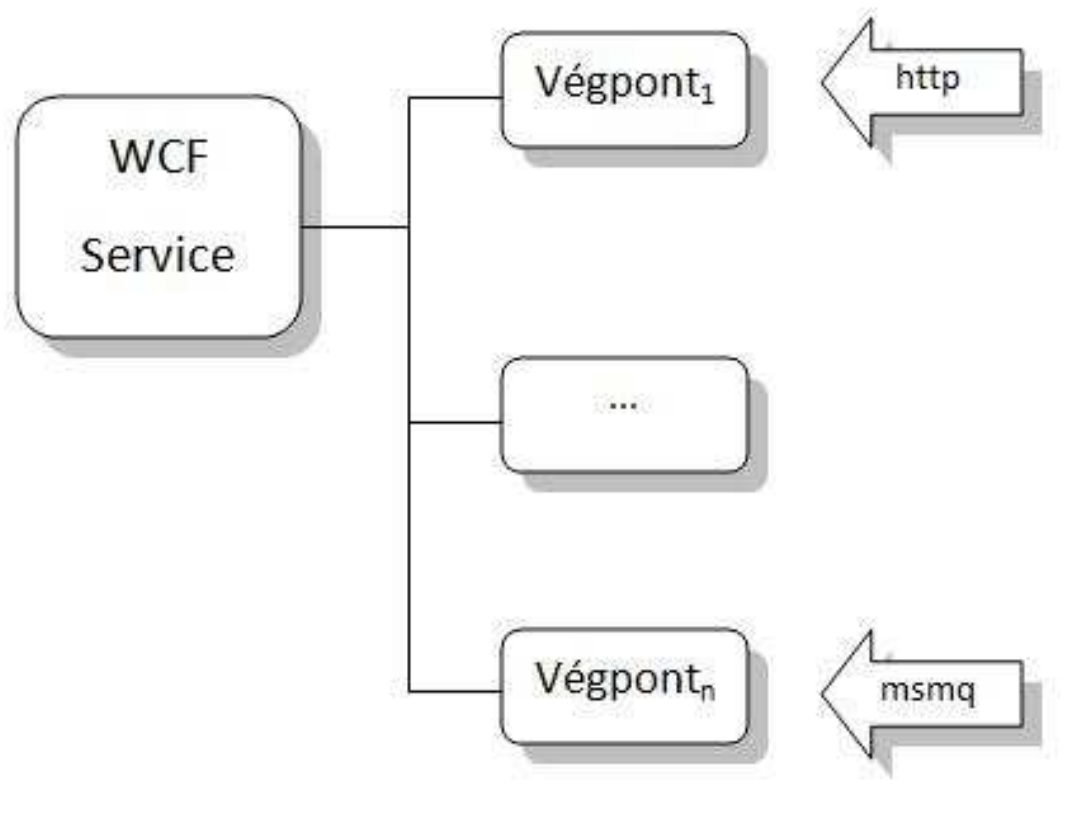

2. ábra - WCF szolgáltatás több végponttal

\subsection{A végpont címe (address)}

A végpont címe egy URI (Uniform Resource Identifier), amely megadja, hogy hol található az adott végpont. A végpont címének megadására a WCF a System.ServiceModel.EndpointAddress osztályt használja. A végpont címét megadhatjuk a kódban, illetve konfigurációs fájlokban. A végponttal kapcsolatos információkat célszerü a konfigurációs fájlokban beállítani, mert módosítás esetén nem kell az alkalmazásunkat újrafordítani vagy a webszerverre kihelyezni. Gondoljunk csak arra, hogy egy alkalmazás fejlesztési fázisában általában nem a végleges címet használjuk, hanem egy tesztszerveren vagy lokálisan futó szolgáltatás címét. Egy másik előnye ennek a módszernek, hogy a fejlesztés után a rendszergazda is módosítani tudja az adott beállítást anélkül, hogy értené a mögöttes implementációt. 
A 3. és 4. ábra egy szolgáltatás végpontjának beállítását szemlélteti konfigurációs fájlban, illetve kódban:

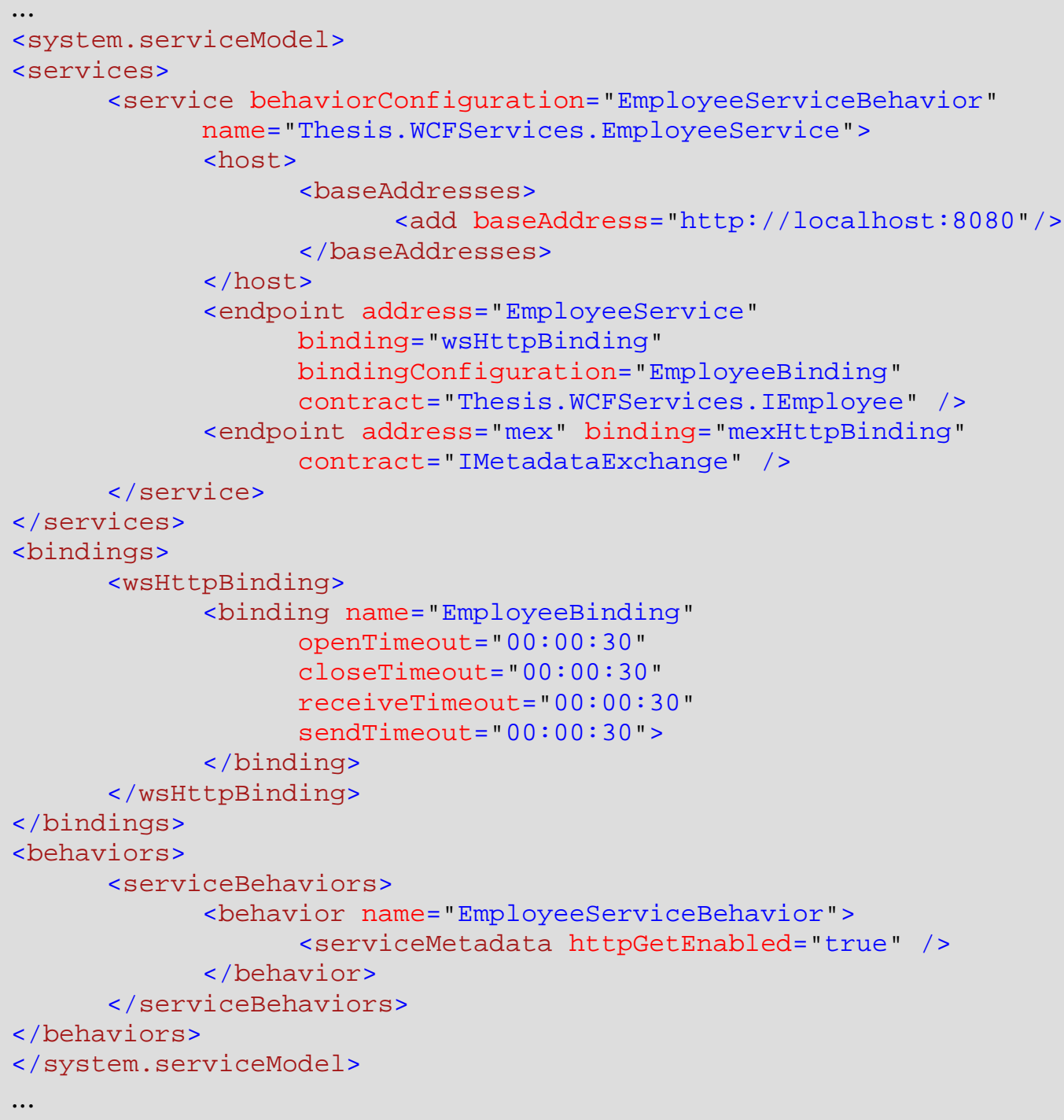

3. ábra-Szolgáltatás végpontjának beállitása konfigurációs fájlban

A végpont megadásánál használhatunk abszolút és relatív címet. Amennyiben relatív címet adunk meg, akkor definiálnunk kell egy báziscímet is, azonban ha Internet Information Services (IIS) segítségével hosztolunk, akkor ne adjunk meg báziscímet, csak relatív címet, mert az .svc fájl 
címe lesz a báziscím (erről a későbbiekben még szó lesz). Ha egy végpontnak nem adunk meg relatív vagy abszolút címet, akkor a báziscím lesz az adott végpont címe. Itt azonban fontos megjegyezni, hogy a végpontok címeinek egyedinek kell lenni, tehát hibához vezet, ha minden végpontnál a báziscímet alkalmazzuk (és természetesen minden más esetben is, ahol sérül ez az egyediségre vonatkozó megszorítás).

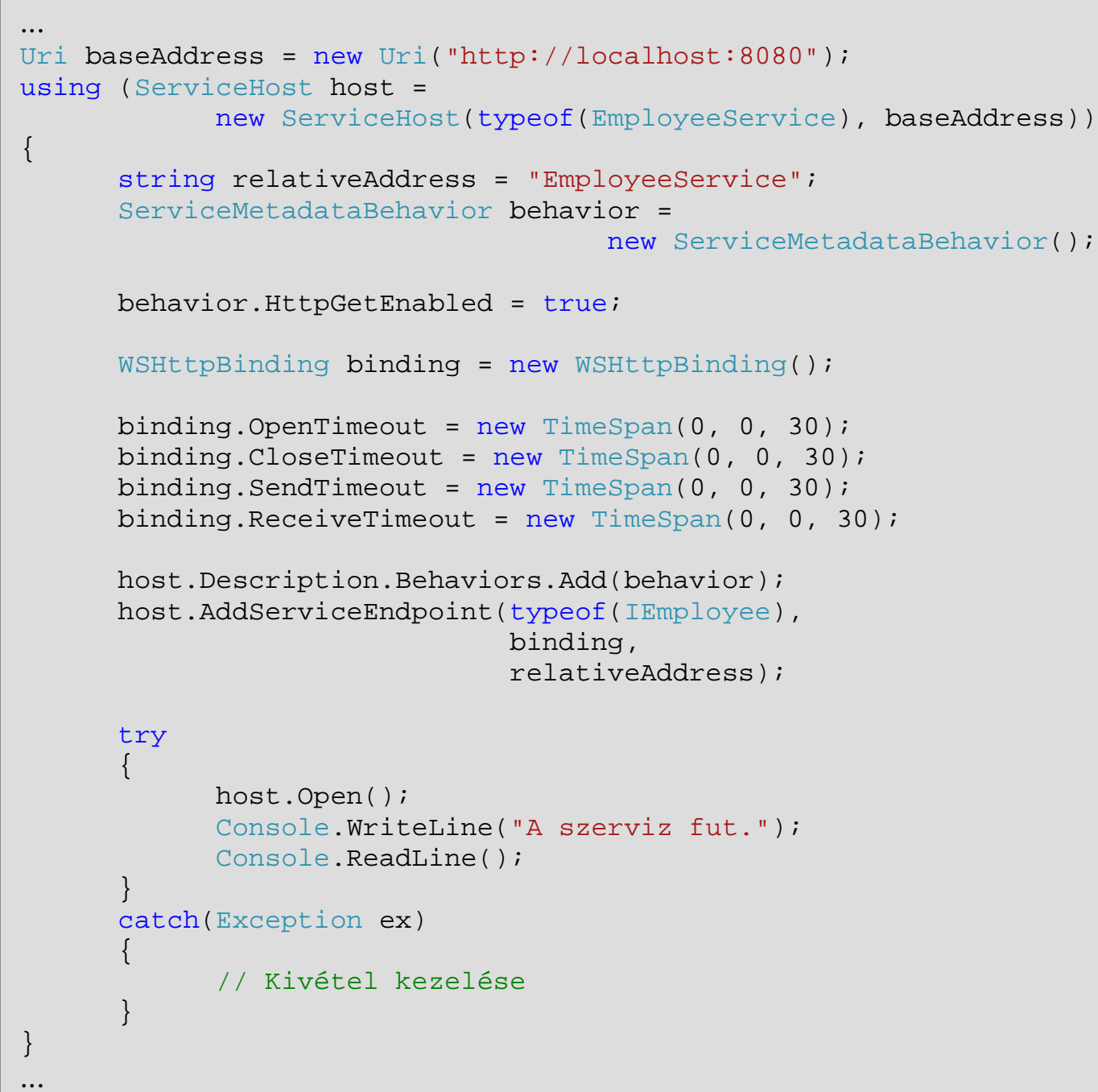

4. ábra - Szolgáltatás végpontjának beállitása kódban 
Megjegyzés:

A kódban szereplő IEmployee interfész a service contract-ot reprezentálja, az EmployeeService osztály pedig ezen interfész implementációjával az üzleti logikát tartalmazza. Ezzel később részletesen foglalkozunk.

A System.ServiceModel névtér ServiceHost osztálya egy hosztot szolgáltat a szolgáltatásnak, melynek típusát megadtuk, báziscímet, viselkedést, illetve végpontot rendeltünk hozzá.

\subsection{Binding}

A binding-ok segítségével megadhatjuk a kommunikáció során használt protokollokat, üzenetkódolási beállításokat, az adatok szállítására vonatkozó információkat. A binding binding elemek gyüjteménye, ahol minden elem a kommunikáció adott tulajdonságára vonatkozik. A WCF segítségével elöre definiált binding-okat is használhatunk, amelyek a binding elemek megfelelő alapértelmezett értékeit képviselik, amelyeken változtathatunk, de lehetőség van saját binding megadására is.

A fenti ábrákon láthattuk a binding megadását konfigurációs fájlban, illetve kódban.

Az <endpoint> elem binding attribútumával megadtuk, hogy a WCF elöre definiált wsHttpBinding binding-ját használja a végpont, illetve a bindingConfiguration attribútum a <bindings> elem megfelelö elemére mutat, ahol a megadott binding beállításain módosíthatunk.

Ha a kódban szeretnénk megadni a binding-ot, akkor azt a ServiceHost példányon hívott AddServiceEndpoint metódus segítségével tehetjük meg. 


\subsection{Service contract}

A contract-ok közül ebben a fejezetben a service contract-ot ismertetem. A Data, Message és Fault contract-ok a későbbi fejezetekben kerülnek bemutatásra.

A szolgáltatások müveletek (operation) csoportjai, ahol a service contract határozza meg, hogy a szolgáltatás milyen müveleteket publikál, azaz egy publikus interfészt biztosít, amelyen keresztül igénybe lehet venni a szolgáltatást. A WCF alkalmazásoknál ezen müveletek megadása metódusok létrehozását jelenti, melyek el vannak látva System.ServiceModel.OperationContractAttribute attribútummal. Service contract létrehozásához megadhatjuk ezen metódusok specifikációját egy interfészben, amely el van látva System.ServiceModel.ServiceContractAttribute attribútummal vagy közvetlenül megadhatjuk implementációval együtt egy osztályban, amely szintén meg van jelölve az előbb említett attribútummal.

Célszerü az interfészek használata, mert így az interfész implementációját megváltoztatva a service contract változatlan marad és több service contract is kiterjeszthető. Azok a metódusok, melyek nincsenek megjelölve OperationContractAttribute attribútummal, nem szolgáltatás müveletek, nem hívhatók a kliens által, de használhatóak a müveletekben a láthatóságuknak megfelelően.

Az alábbi példában a service contract-ot egy interfész segítségével adjuk meg:

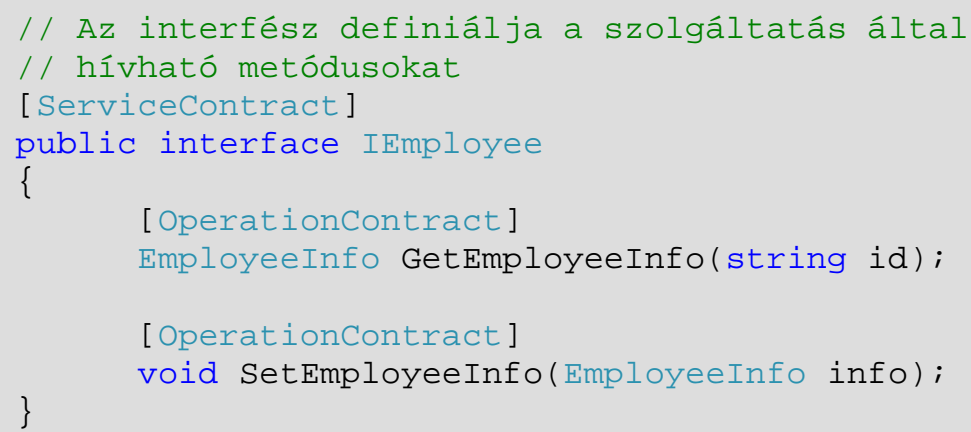

5. ábra-Service contract megadása interfészben 
A contract szó jelentése szerződés, tehát a service contract egy megállapodás a szolgáltatás és a kliens között arról, hogy milyen metódusokat hívhat a kliens, a kommunikáció milyen irányú, stb. Ezekről szó lesz a későbbiekben.

A fenti interfész egy service contract-ot definiál, ahol a két OperationContractAttribute attribútummal ellátott metódus az adott szolgáltatás publikus interfészét jelenti majd, azaz a kliens számára elérhetővé válik.

Az alábbi ábra a fentebb definiált interfész egy implementációját mutatja, ahol implementáljuk az interfészt, azaz logikát adunk a specifikációkhoz.

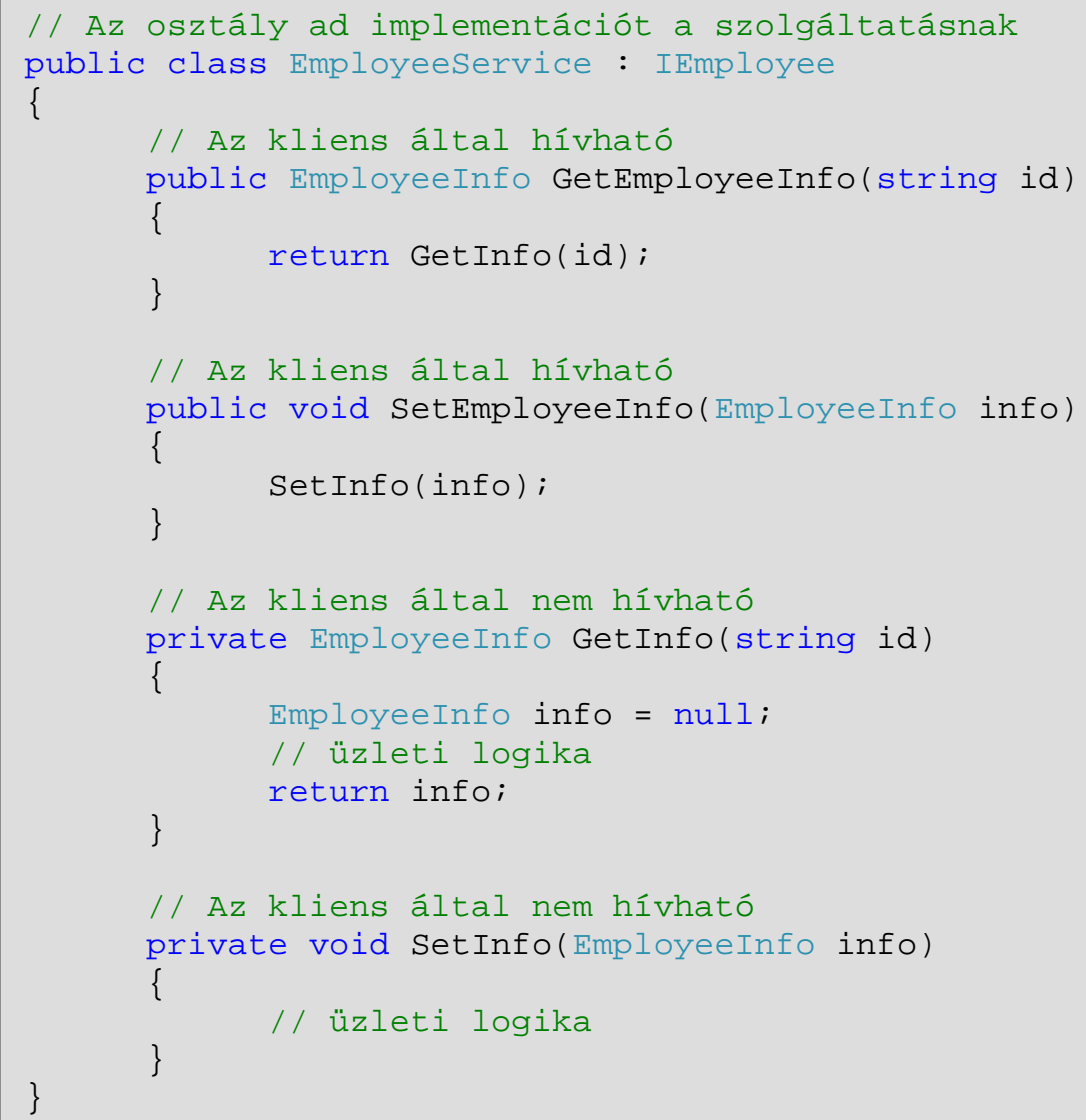

6. ábra-Service contract implementációja 
Azok a metódusok, amelyek a service contract-ban nincsenek ellátva OperationContractAttribute attribútummal, azok nem képezik a szolgáltatás és a kliens közötti megállapodás részét, ezáltal a kliens számára elérhetetlenek.

Az OperationContractAttribute attribútum a megjelölt metódust a service contract részévé teszi, és bizonyos viselkedéseket írhat elő a metódusra nézve. Például:

- hívása munkamenetet indíthat

- lezárhat egy munkamenetet

- aszinkron módon hívható

- megadja a kommunikáció irányát

A következő fejezet a szolgáltatás hosztolási lehetőségeit mutatja be. 


\section{Hosztolás}

Ahhoz, hogy egy szolgáltatás működőképes legyen, szükség van futtató környezetre, amely kezeli a szolgáltatás életciklusát. A WCF többféle hosztolási lehetőséget támogat:

- Self-hosting (hosztolás menedzselt alkalmazásban)

- Windows Process Activation Service (WAS)

- Windows Service

- IIS

Ahhoz, hogy az adott szituációban a legmegfelelőbbet alkalmazzuk, meg kell vizsgálnunk a következő területeket:

- Elérhetőség

- Menedzselhetőség

- Verziókezelés

- Megbízhatóság

A WCF lehetővé teszi, hogy anélkül váltsunk a hosztolási módok között, hogy a szolgáltatás implementációján változtatnunk kellene. A fejezet további részében a self-hosting és a WAS hosztolási módot mutatom be.

\subsection{Self-hosting}

A WCF szolgáltatások szabadon hosztolhatók menedzselt alkalmazásokban. A szolgáltatás kódját beágyazzuk a menedzselt kódba, és ott gondoskodunk az életciklusának kezeléséről. Ezt a módot egyszerü alkalmazni, ugyanis elég néhány sor kódot írni hozzá, és máris futtathatjuk a szolgáltatást. Az életciklust is kezelhetjük a ServiceHost példány Open és Close metódusaival. A 
további beállításokat (végpont, binding, stb.) is a kódban vagy konfigurációs fájlok segítségével adjuk meg. A hibakeresés leegyszerüsödik, ugyanis az adott alkalmazás hosztolja a szolgáltatást, azonban a hátrányai közé tartozik, hogy a szolgáltatás csak akkor elérhető, ha a hosztoló alkalmazás is, illetve nem támogat olyan menedzselési funkciókat, mint az IIS (például verziókezelést).

Ennek a hosztolási módszernek a tipikus esete, amikor konzol alkalmazás segítségével hosztoljuk a szolgáltatást. Ez a fejlesztési fázisban megkönnyíti a hibakeresést és megnöveli a kód mozgathatóságát. Az erre vonatkozó példát már bemutattam a Végpontok című fejezetben.

\subsection{Windows Process Activation Service (WAS)}

A WAS elönye az IIS-sel szemben, hogy nem függ a HTTP protokolltól. Miután a service contract-ot létrehoztuk és implementáltuk, nincs szükség másra a kódban. A szükséges beállításokat a konfigurációs fájlban kell elhelyezni. Létre kell hoznunk egy .svc fájlt és elhelyezni az IIS virtualis könyvtárában. A Microsoft Visual Studio segítségével létrehozhatjuk ezt a fájlt a WCF Service sablont választva.

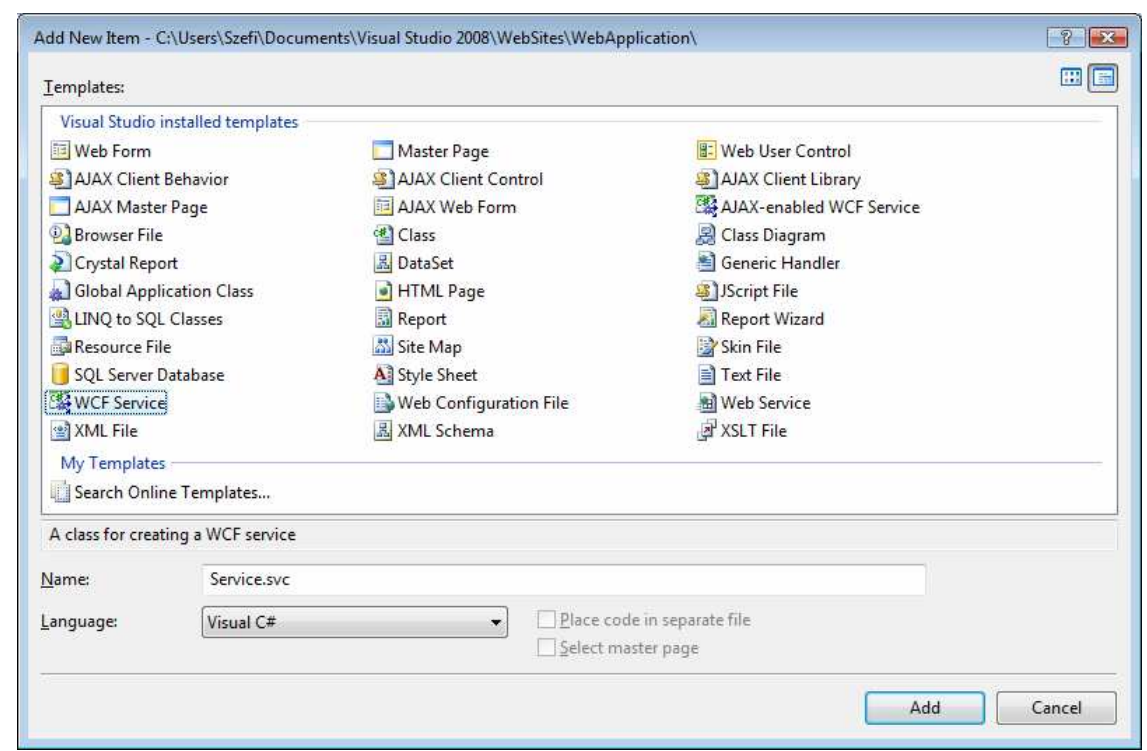

7. ábra-WCF Service sablon 
A .svc fájlban a következő sort helyezzük el, ahol megadjuk a szolgáltatás típusát:

<\% CerviceHost Language="C\#" Debug="true"

Service="Thesis.WCFServices.EmployeeService" \% $>$ 


\section{4 Üzenetváltási modellek}

A WCF a következő üzenetváltási modelleket támogatja:

- Request/Reply (kérés/válasz)

- One-way (egyirányú)

- Duplex

A következő alfejezetek ezeknek a modelleknek a tulajdonságait, alkalmazásukat mutatják be.

\subsection{Kérés/válasz alapú üzenetváltás}

Ebben az üzenetváltási modellben a kliens kérést küld a szolgáltatásnak, majd erre választ kap. Ez az alapértelmezett minta. Ebben a modellben a service metódus hívásakor az input paramétereken és a visszatérési értéken kívül out és ref paraméter(ek) használatára is lehetőség van. Ha nincs visszatérési érték megadva, akkor is érkezik válasz a kliensnek egy üres üzenet formájában, amely jelzi, hogy a metódus visszatért (az egyetlen lehetőség a válasz üzenet elkerülésére az egyirányú kommunikációs minta használata).

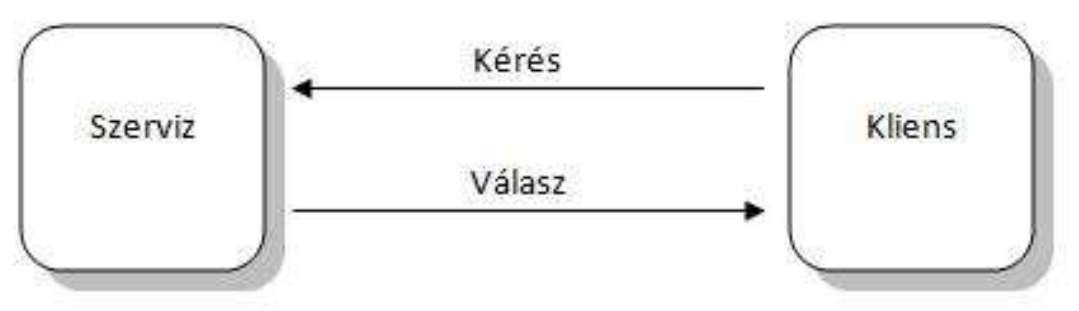

8. ábra-Kérés/válasz alapú üzenetváltási modell

Ez a kommunikációs modell csökkentheti a kliens teljesítményét, ha a metódus hosszú ideig fut. Ezt a problémát elkerülhetjük, ha egyirányú kommunikációt folytatunk. Ennek azonban az a 
hátránya, hogy nincs válasz üzenet (A későbbiekben látni fogjuk az aszinkron modell használatát, amely segítséget nyújt ezen problémák megoldásában.). Ha visszatérési típus helyett a void kulcsszót adjuk meg, akkor is van értelme, illetve előnye ennek a kommunikációs formának: a válasz üzenetből a hívás során keletkezett hibákról a kliens tudomást szerezhet.

Kérés/válasz alapú service metódus létrehozásakor beállítjuk az OperationContractAttribute attribútum IsOneWay property-jének értékét false-ra (ez az alapértelmezett érték).

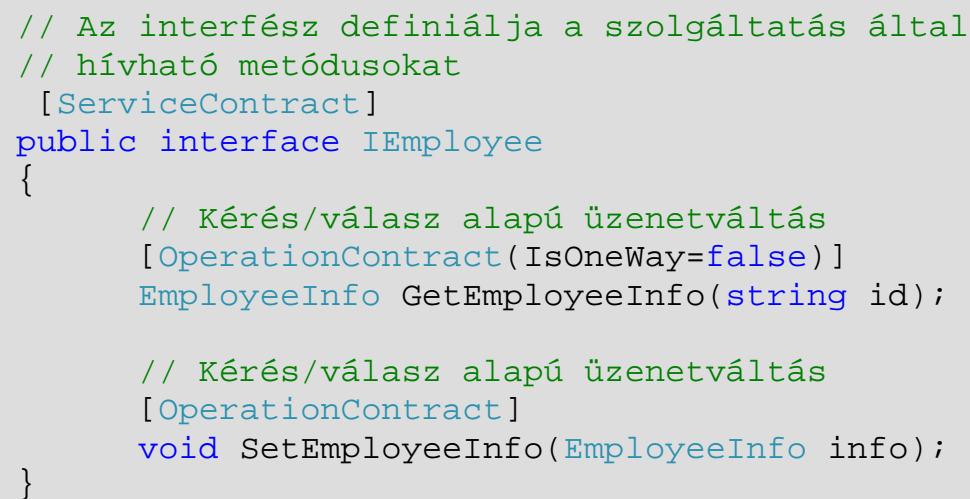

9. ábra - Kérés/válasz alapú üzenetküldés beállítása a service contract-ban.

\subsection{Egyirányú üzenetküldés}

Ezt a kommunikációs modellt akkor érdemes használni, ha a kliens nem akar vagy nem tud várni, amíg a service metódus lefut, vagy nincs szüksége válaszra (például az Observer tervezési minta esetén a feliratkozottak értesítése nem igényel választ). Ebben az esetben a kliens nem tudja kezelni a kommunikáció során felmerülő SOAP hibákat sem. Nincs visszatérési érték, nem használható out és ref paraméter, ugyanis nincs válasz üzenet, amely visszaadná az értéket. 


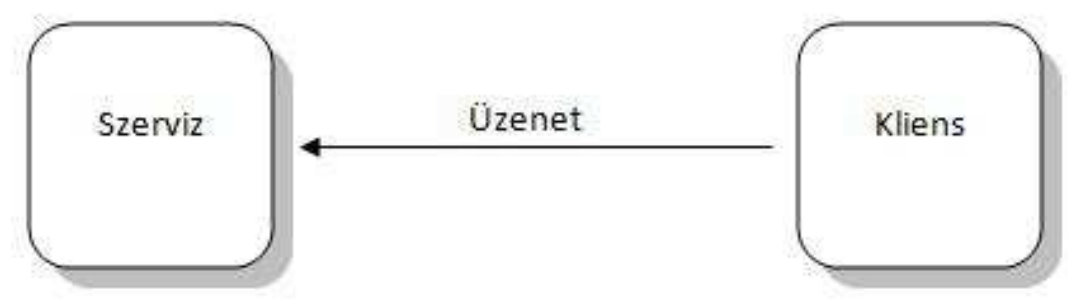

10. ábra - Egyirányú üzenetküldési modell

Egyirányú service metódus létrehozásakor beállítjuk az OperationContractAttribute attribútum IsOneWay property-jének értékét true-ra (false az alapértelmezett érték).

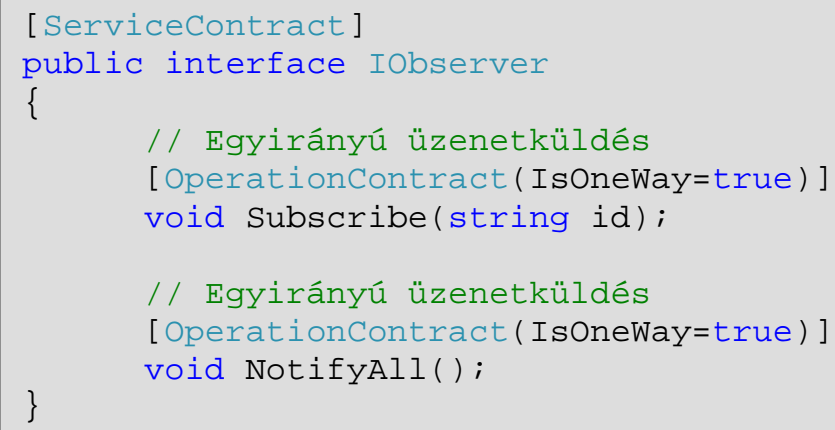

11. ábra - Egyirányú üzenetküldés beállítása a service contract-ban.

\subsection{Duplex modell}

A duplex kommunikációs modellben a szolgáltatás és a kliens egymástól függetlenül küldhet üzeneteket a másiknak egyirányú vagy kérés/válasz típusú üzenetküldéssel. 


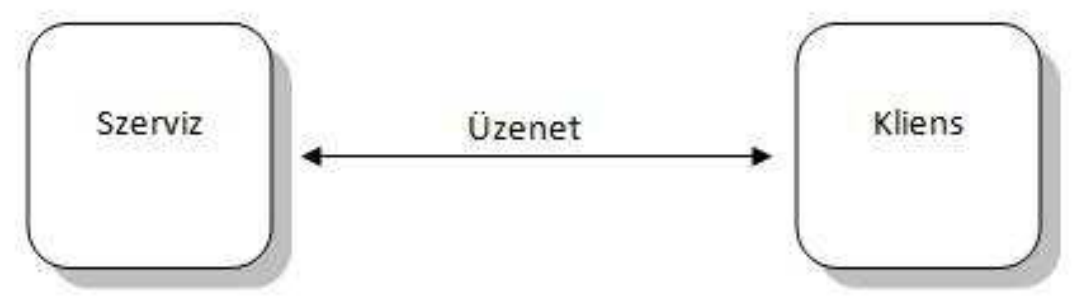

12. ábra-Duplex üzenetküldési modell

A duplex service contract mellé létre kell hozni egy másik interfészt is, amelyben megadjuk azon metódusok specifikációját, amelyeket a szolgáltatás hívhat a kliensen. Az implementáció természetesen a kliens oldalon kerül megadásra. Itt is használjuk az OperationContractAttribute attribútumot azon metódusokra, melyek publikusak lesznek a szolgáltatás felé.

A callback interfész típusát meg kell adnunk a ServiceContractAttribute attribútum CallbackContract property-jének.

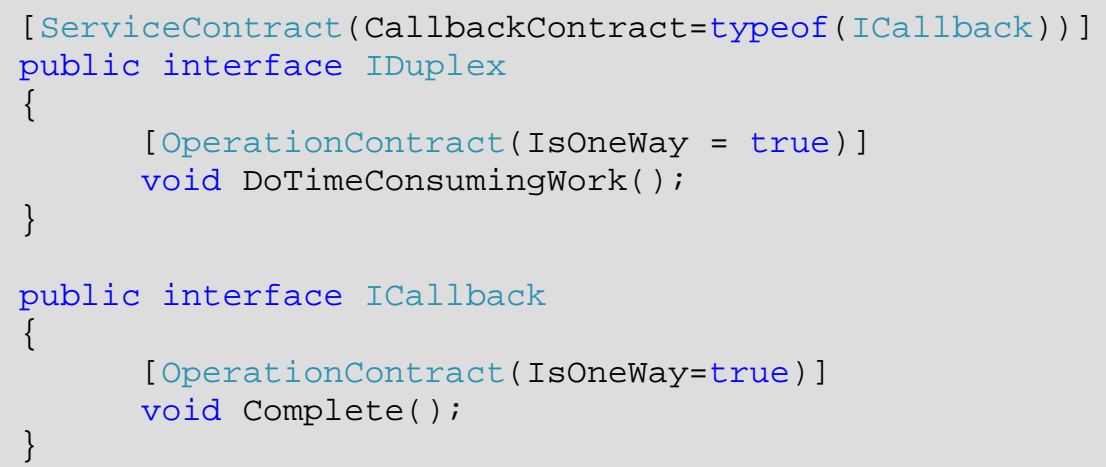

13. ábra-Service és callback contract

Ezután implementáljuk a service contract-ot definiáló interfészt. Ekkor az OperationContext.Current.GetCallbackChannel $<T>()$ metódussal hozzáférhetünk a kliens publikus interfészéhez, azaz meghívhatjuk azokat a metódusokat, amelyeket a kliens publikált. 


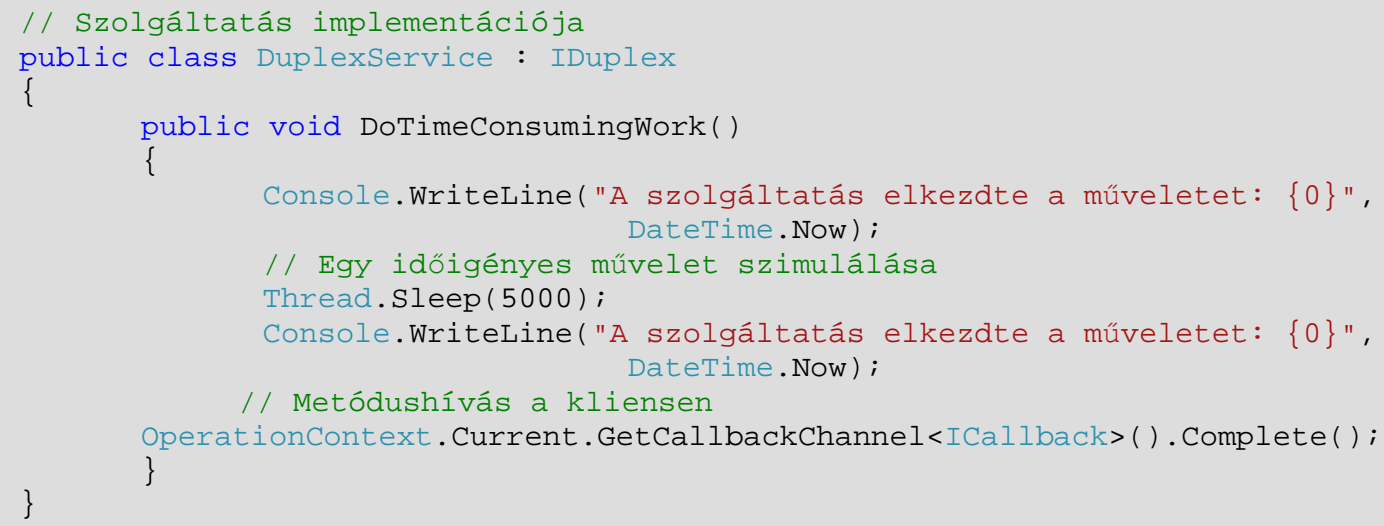

\section{4. ábra - A szolgáltatás implementációja}

A kliens oldalon adjunk implementációt a callback interfészhez. Hozzunk létre egy InstanceContext objektumot, melynek konstruktorában adjuk át az implementált interfész egy példányát. Ezen a példányon hívja majd a szolgáltatás a publikált metódusokat. Az InstanceContext példányt pedig adjuk át a service proxy konstruktorának példányosításkor.

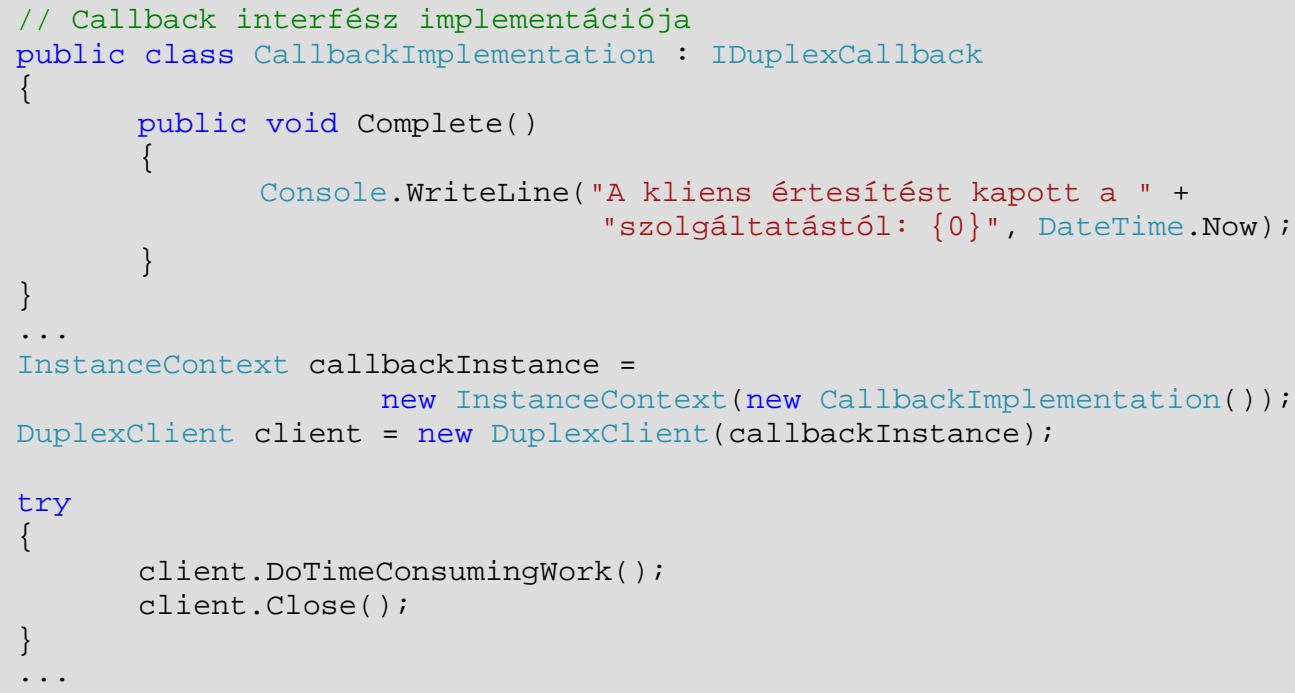

15. ábra-Callback interfész implementálása és a service proxy példányositása. 
Megjegyzés:

A kliens oldal felépítésében elengedhetetlen eszköz a ServiceModel Metadata Utility Tool (svcutil.exe), melynek segítségével könnyedén generálhatjuk a szolgáltatás proxy infrastruktúráját, illetve a szükséges konfigurációs fájlt. 


\section{Szerializáció}

A .NET keretrendszer kétféle szerializálást használ: bináris és XML szerializálást. Bináris esetben a küldő és fogadó félnek azonos platformmal és futtató rendszerrel kell rendelkeznie, de a szolgáltatás orientált alkalmazásoknál gyakori, hogy a kommunikáció végpontjain különböző nyelveken írt programok futnak, akár különböző operációs rendszert felhasználva. Ekkor is elvárható az a müködés, hogy a két fél fel tudja dolgozni a megkapott adatokat. Ehhez nyújt segítséget az XML szerializálási technika, melynek során memóriabeli objektumból XML adat keletkezik, majd a deszerializálás során visszakapjuk az objektumot.

A WCF szolgáltatások esetén a kliens és a szerver a kommunikáció során adatot cserélnek. Ezt a műveletet paraméterek átadásával, illetve visszatérési érték formájában valósítják meg. Az üzenetben szereplő adatok reprezentációja XML, tehát szerializációra is szükség van, mielött az adat a csatornára kerül, és deszerializációra, mielőtt a másik oldal feldolgozná azt. A primitív típusokat (int, float, byte, stb.) módosítás nélkül használhatjuk, viszont a felhasználó által definiált típusokat szerializálhatóvá kell tennünk. Ehhez nyújt segítséget a következő két WCF által támogatott XML szerializáló mechanizmus.

\subsection{DataContractSerializer}

Ez az alapértelmezett szerializálási technika. Ezen mechanizmus használatához az adott osztályra alkalmazni kell a System.Runtime.Serialization.DataContractAttribute attribútumot, illetve a szerializálandó adattagokra a System.Runtime.Serialization.DataMemberAttribute attribútumot. Csak azok az adattagok kerülnek szerializálásra, amelyek meg vannak jelölve ezzel az attribútummal. (A DataContractAttribute attribútum osztályokon kívül struktúrákra és felsorolásos típusokra is alkalmazható.) Példaként tekintsük az alábbi osztályt: 


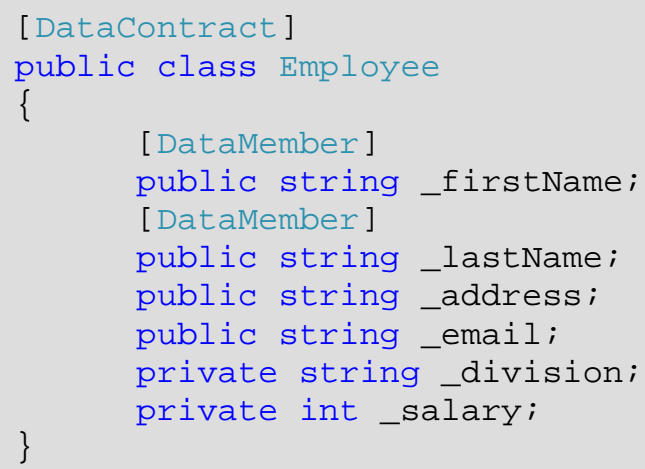

\section{6. ábra - Szerializálás DataContractSerializer használatával}

A_firstname és_lastname public láthatóságú változókra alkalmaztam a DataMemberAttribute attribútumot, melynek hatására ezek a változók részt vesznek a szerializálási folyamatban. A kliens oldalon visszakapott Employee példány a következő változókat mutatja:

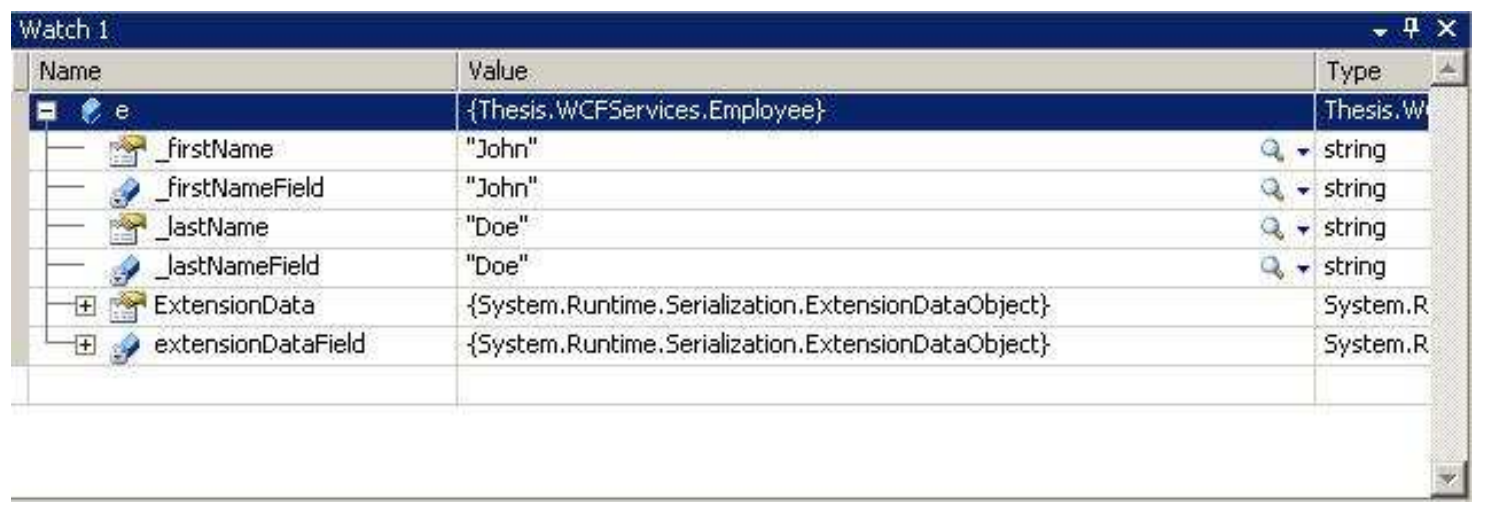

17. ábra - A deszerializálás eredménye

A kliens és szerver kommunikációja során nem kötelező, hogy az üzenetváltásnál használt típusok a csatorna mindkét végén létezzenek. Elégséges a data contract egyenlősége. Két data contract akkor egyenlő, ha a következő feltételek mindegyike teljesül:

- Azonos a nevük. 
- Az összes tartalmazott DataMember attribútummal ellátott adattag neve és sorrendje megegyezik.

Megjegyzés: A DataContract, illetve DataMember nevei alapértelmezésként a megjelölt osztályok, adattagok nevei, de az attribútum Name property-je segítségével felül lehet bírálni.

A sorrendnél fontos megjegyezni, hogy az alapértelmezett rendezés ábécé szerinti, de a DataMember attribútum Order property-je segítségével ez felülbírálható. Az alábbi ábrán két ekvivalens data contract szerepel:

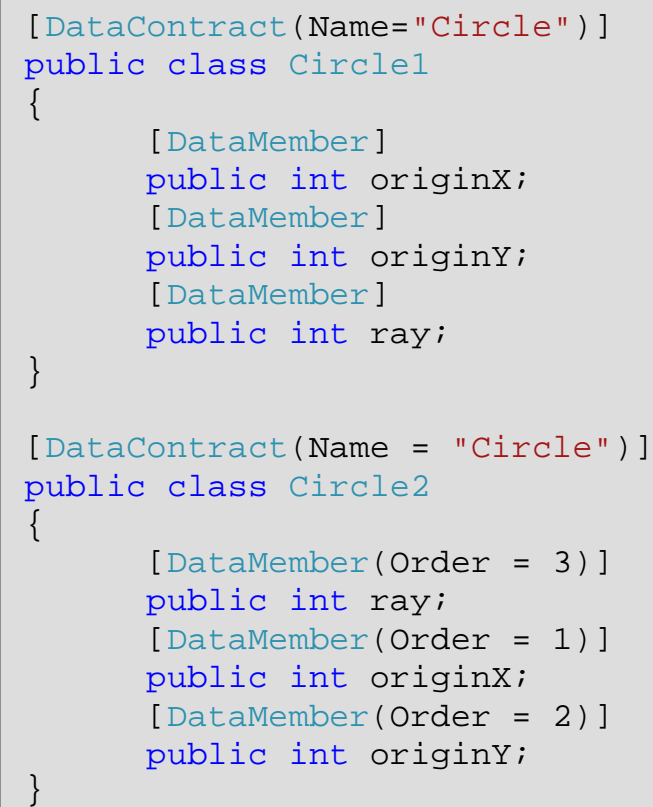

18. ábra-Ekvivalens data contract-ok

Leszármazott típusok esetén a sorrendnél a szülőosztály adattagjainak sorrendjét, majd a fennmaradó adattagok sorrendjét vesszük alapul. 
A kommunikáció során gyakran használunk olyan típusú paramétereket, visszatérési értékeket, melyek nem képezik a data contract részét, de kötődnek hozzá. Ilyen előfordulhat abban az esetben, ha a data contract-ban a konkrét típus helyén valamilyen interfész típusú, bázisosztály típusú (akár object, akár más) eszköz szerepel. Ekkor a szerializálás sikere ellenére a deszerializálás hibás lesz, mert a másik fél nem tudja azonosítani az adott típust, mivel nem szerepel a data contract-ban. E probléma megszüntetésére használhatjuk a System.Runtime.Serialization.KnownTypeAttribute attribútumot. Használatára nézzünk egy példát:

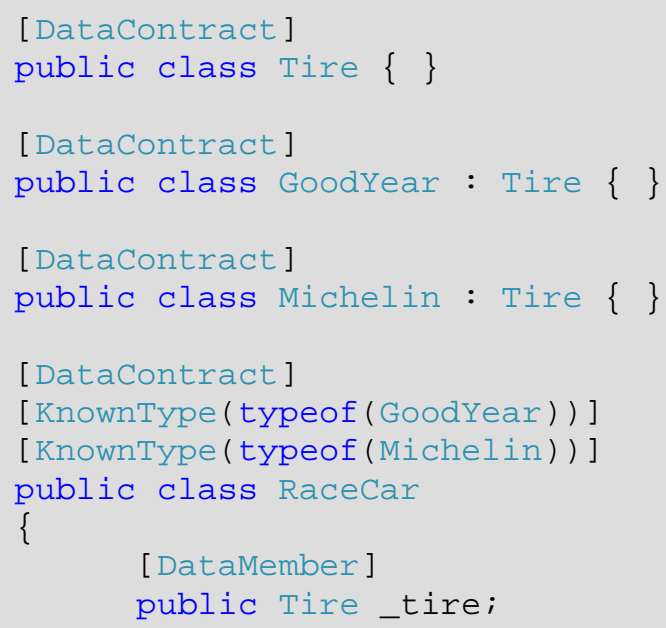

19. ábra - KnownType attribútum használata

(A fent említett kapcsolódó típusokat a konfigurációs fájlokban is beállíthatjuk.)

Lehetőség van arra, hogy egy típust előre kompatibilissé tegyünk. Ehhez implementálnunk kell a System.Runtime.Serialization.IExtensibleDataObject interfészt, mely tartalmazza az ExtensionData property definícióját. Ha a WCF olyan adatot talál, amelyik nem része a data contract-nak, akkor eltárolja azt ebben a property-ben. 
Előfordulhat, hogy a kommunikáció egyik oldalán egy data contract olyan újabb verziója szerepel, amelyben a régihez képest újabb adattagok is szerepelnek. Felmerülhet az igény arra, hogy a (de)szerializálás valamely szakaszában kezeljük a verzionális eltéréseket, például adjunk alapértelmezett értéket az adott adattagnak. Ehhez nyújt segítséget a System.Runtime.Serialization névtér alábbi 4 attribútuma:

- OnSerializingAttribute

A megjelölt metódus a szerializálás előtt hívódik meg.

- OnSerializedAttribute

A megjelölt metódus a szerializálás után hívódik meg.

- OnDeserializingAttribute

A megjelölt metódus a deszerializálás előtt hívódik meg.

- OnDeserializedAttribute

A megjelölt metódus a deszerializálás után hívódik meg.

\subsection{XmlSerializer}

Az alapértelmezett szerializálás a System.Runtime.Serialization.DataContractSerializer osztály segítségével történik, ezért ha az System.Xml.Serialization.XmlSerializer-t szeretnénk használni, akkor a szolgáltatást meg kell jelölni az XmlSerializerFormatAttribute attribútummal. Az XmlSerializer a típusok szűkebb körét támogatja, de nagyobb kontrollt biztosít az XML szerkezetének felépítéséhez.

A szerializáló mechanizmusok váltogatása nagy körültekintést igényel, ugyanis elöfordulhat, hogy nem ugyanaz lesz az eredmény. Kimaradhatnak vagy éppen megjelenhetnek olyan adatok, melyeknek nem kellene. Míg a DataContractSerializer esetén csak a DataMemberAttribute attribútummal megjelölt adattagok kerülnek szerializálásra, addig az XmlSerializer használatával minden publikus adattag. 
Példaként tekintsük ismét a fentebb említett Employee osztályt. Szerializáljuk most az XmlSerializer osztály segítségével.

\begin{tabular}{|c|c|c|c|}
\hline Watch 1 & & & $-4 x$ \\
\hline Name & Yalue & & Type \\
\hline E\&e & TThesis.WCFServices.Employee\} & & Thesis.w \\
\hline - Y address & "New York" & Q. & string \\
\hline _ 9 _addressField & "New York" & $Q+$ & string \\
\hline - I email & "john@doe.com" & $Q_{*}$ & string \\
\hline - 9 _emailField & "john@doe.com" & Q. & string \\
\hline - firstName & "John" & Q. & string \\
\hline-1 firstNameField & "John" & Q. & string \\
\hline - & "Doe" & $Q_{2}$ & string \\
\hline - \& lastNameField & "Doe" & $a_{1}$ & string \\
\hline$\mp$ ExtensionData & \{System.Runtime.Serialization.ExtensionDataObject\} & & System. \\
\hline
\end{tabular}

20. ábra - A deszerializálás eredménye

Láthatjuk, hogy ebben az esetben az Employee osztály minden publikus adattagja megjelenik a kliens oldalon.

\subsection{Message Contract}

Előfordulhat olyan szituáció, amikor nem csak az üzenetben küldött adatok szerkezetének meghatározása lényeges, hanem az üzenet szerkezete is. A típusok SOAP üzenetté történő leképezéséhez nyújt segítséget a System.ServiceModel.MessageContractAttribute attribútum, valamint a System.Messaging.Message osztály. Ekkor megadhatjuk, hogy mely adattagok képezzék az üzenet fejrészét, törzsét. Amennyiben használni szeretnénk ezt a funkciót, akkor olyan service metódusokat kell írnunk, melyek legfeljebb 1 paraméterrel rendelkeznek, illetve van visszatérési értékük. Mindkét esetben a típust meg kell jelölni a MessageContractAttribute attribútummal vagy Message típusúnak kell lennie.

Egy típust a MessageContractAttribute attribútummal megjelölve data contract-tá tehetünk. Ha a típus adattagjait a System.ServiceModel.MessageHeaderAttribute attribútummal jelöljük meg, 
akkor azok a SOAP fejlécbe kerülnek, System.ServiceModel.MessageBodyMemberAttribute esetén pedig a törzsbe.

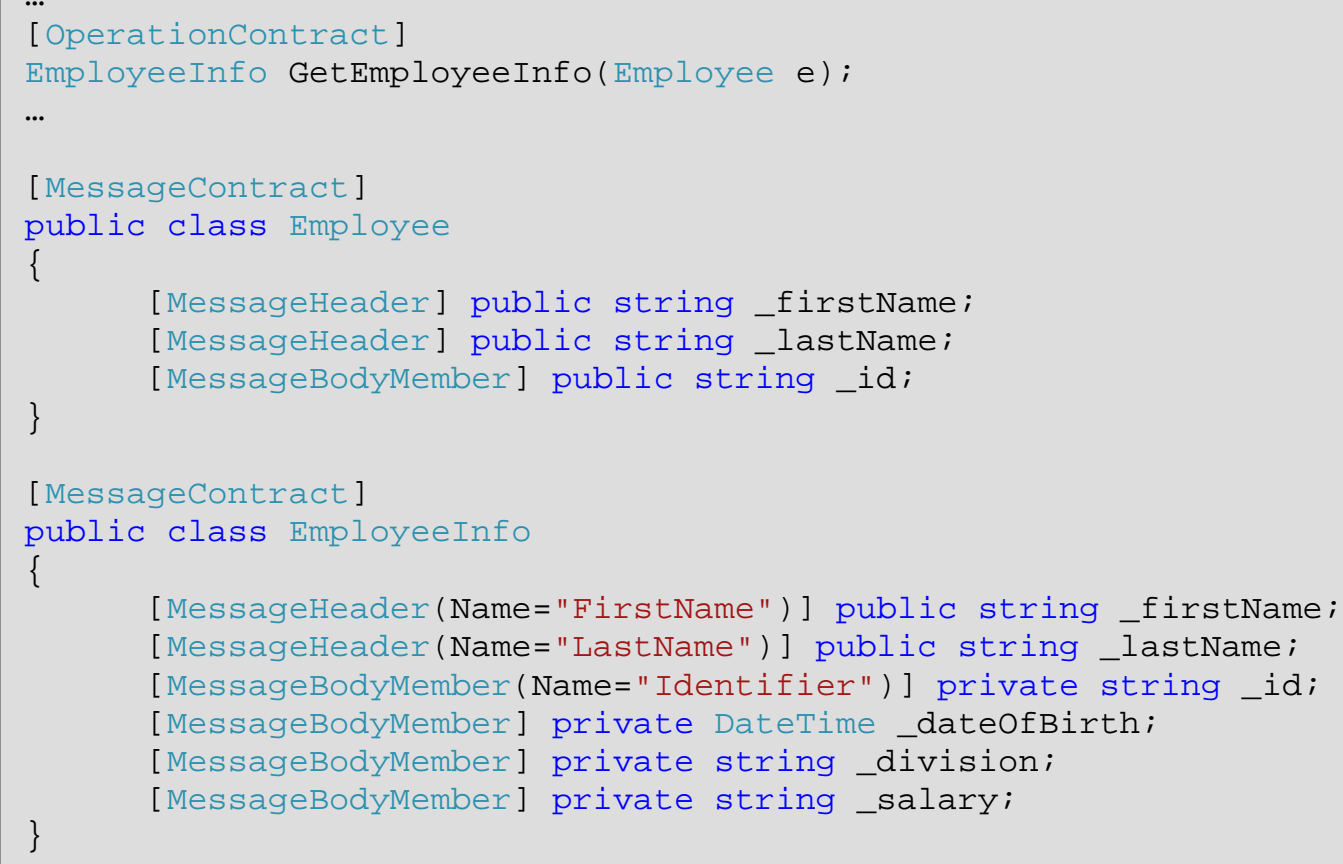

\section{1. ábra-Message contract használata}

Az üzenetben szereplő adatokat védeni tudjuk, ha a MessageHeaderAttribute és MessageBodyMemberAttribute attribútumok ProtectionLevel property-jét beállítjuk.

Lehetséges értékei:

- None (nincs titkosítás és digitális aláírás)

- Sign (digitális aláírás)

- EncryptAndSign (titkosítás és digitális aláírás)

A fejrészre külön-külön is beállíthatjuk az értékeket, a törzsre viszont a legerősebb érték kerül alkalmazásra. 
A WCF lehetőséget nyújt arra, hogy az üzenetet szürjük, mellyel különböző értékekre különböző futásidejü viselkedést írhatunk elö. A szürés az üzenet beérkezése után hajtódik végre (Például, amikor egy sor alapú rendszerbe üzenet érkezik, akkor dönthetünk arról, hogy egy magasabb prioritású üzenet a sorban elörébb jusson.). Szürhetjük az Action header-t, a végpont címét vagy annak egy prefixét, illetve XPath kifejezés segítségével eldönthetjük, hogy az adott XML dokumentum tartalmaz-e egy adott elemet, attribútumot, stb. A WCF üzenet szürői a következök:

- MatchAllMessageFilter

Az összes üzenetre illeszkedik.

- MatchNoneMessageFilter

Egyik üzenetre sem illeszkedik.

- XPathMessageFilter

Egy XPath kifejezés segítségével dönt az illeszkedésröl.

- EndpointAddressMessageFilter

A végpont címére szür.

- PrefixEndpointAddressMessageFilter

A végpont címének prefixére szür. 


\section{Aszinkron programozási modell (APM)}

A .NET keretrendszer lehetővé teszi, hogy utasításokat futtassunk nemlineáris módon, ezáltal az alkalmazásunk teljesítménye megnő, a válaszidők lecsökkennek, bizonyos szűk keresztmetszetek eltünnek és a rendszer erőforrásai magasabb hatásfokkal működnek.

Az aszinkron modell használatával meghatározott kódrészek külön szálon futnak, lehetővé téve, hogy egy hosszabb futás alatt (pl.: nyomtatás, IO műveletek) az alkalmazás más teendőket is végezzen. A keretrendszer jónéhány osztálya rendelkezik az aszinkron modellt megvalósító BeginX és EndX metódusokkal, például a FileStream osztályban megtalálhatjuk a BeginRead és EndRead metódusokat.

A BeginX metódusok sajátossága, hogy System.IAsyncResult objektummal térnek vissza, illetve két formális prarméterrel rendelkezniük kell: egy System.AsyncCallback és egy object típusú paraméterrel.

IAsyncResult BeginRead(byte[] array, int offset, int numBytes, AsyncCallback userCallback, object stateobject);

Az EndX metódusoknak rendelkezniük kell egy IAsyncResult típusú formális paraméterrel.

int EndRead(IAsyncResult asyncResult);

Programunkat képessé kell tenni arra, hogy egy aszinkron futás végéröl tudomást szerezzen, és eredményét fel tudja dolgozni. Erre 3 modellt ismertetnék: a Wait-Until-Done modellt, a Polling modellt, illetve a Callback modellt. 


\subsection{Wait-Until-Done modell}

Ez tükörfordításban annyit jelent, hogy "várj, amíg nincs kész". Ez a modell is lehetővé teszi, hogy más utasítások fussanak a BeginX és EndX metódushívások között, de ha ezen utasítások hamarabb lefutottak, mint ahogy az aszinkron hívás visszatér, akkor a fő szál blokkolt állapotba kerül, megvárja a hívás eredményét.

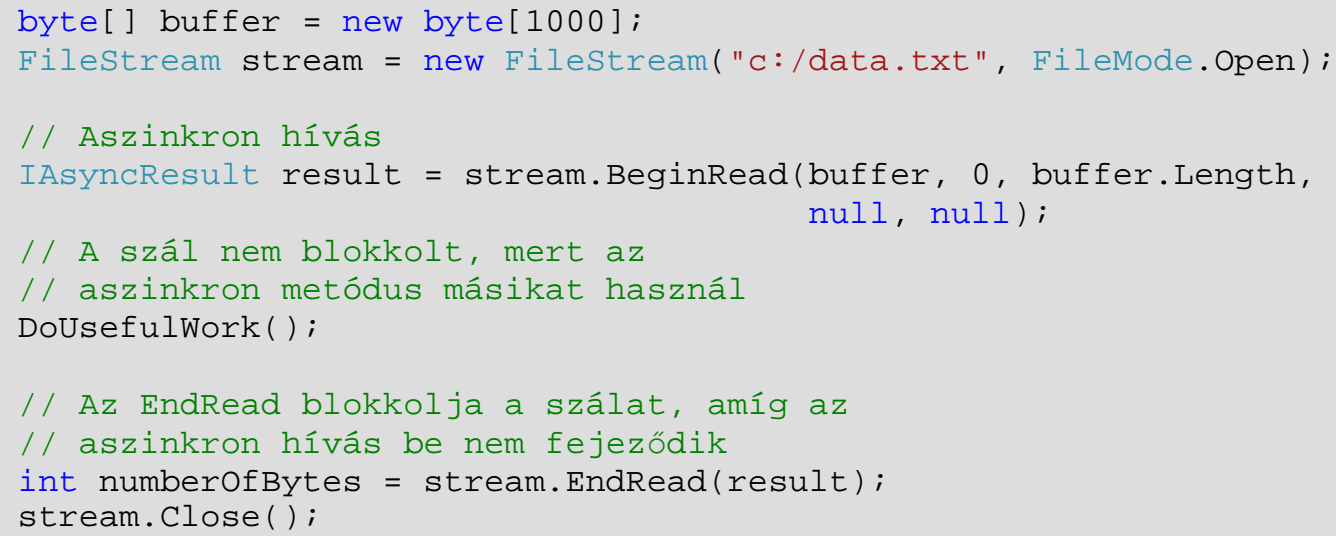

22. ábra-Wait-Until-Done modell

Ez a modell nem nyújt megfelelő segítséget, szűk keresztmetszeteket, hosszú várakozást eredményezhet.

\subsection{Polling modell}

Ez a modell megvizsgálja az IAsyncResult objektum (az IAsyncResult interfészt implementáló osztály példánya) IsComplete property-je segítségével, hogy az adott aszinkron hívás visszatért-e. Ha nem, akkor addig értékes műveleteket lehet végezni. 


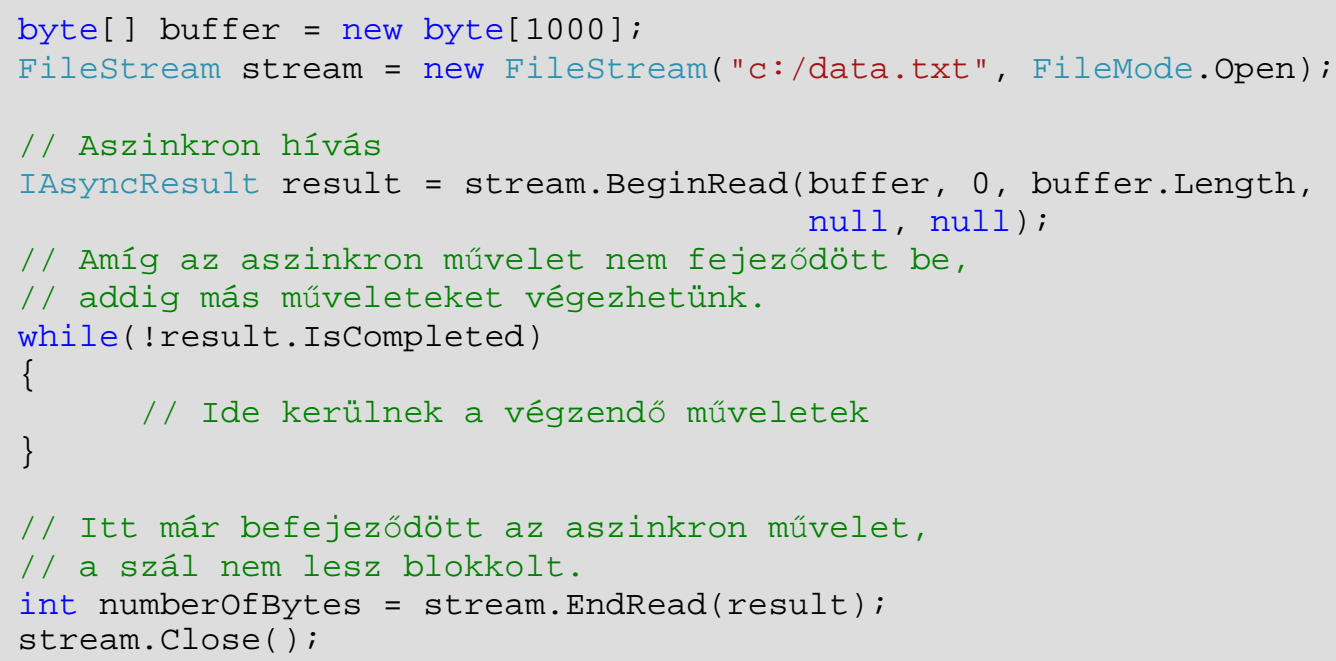

23. ábra-Polling modell

Ez a modell feltételezi, hogy az alkalmazásnak az aszinkron művelet alatt van más teendője is. Ez a legtöbb esetben nem teljesül, ezért az igazi megoldást a Callback modell nyújtja.

\subsection{Callback modell}

Ez a modell nyújtja a legkényelmesebb szolgáltatást, ugyanis megadhatunk egy metódust, ami meghívódik, ha az aszinkron müvelet befejeződött. A müvelet által visszaadott objektumot feldolgozó logikát pedig elhelyezhetjük ebben a metódusban.

A BeginX metódus AsyncCallback típusú paraméterének (ami egy delegate) megadunk egy AsyncCallback példányt, amire felirattuk a meghívandó metódusunkat. A metódusnak egy IAsyncResult paraméterrel kell rendelkeznie, és nem lehet visszatérési értéke. 


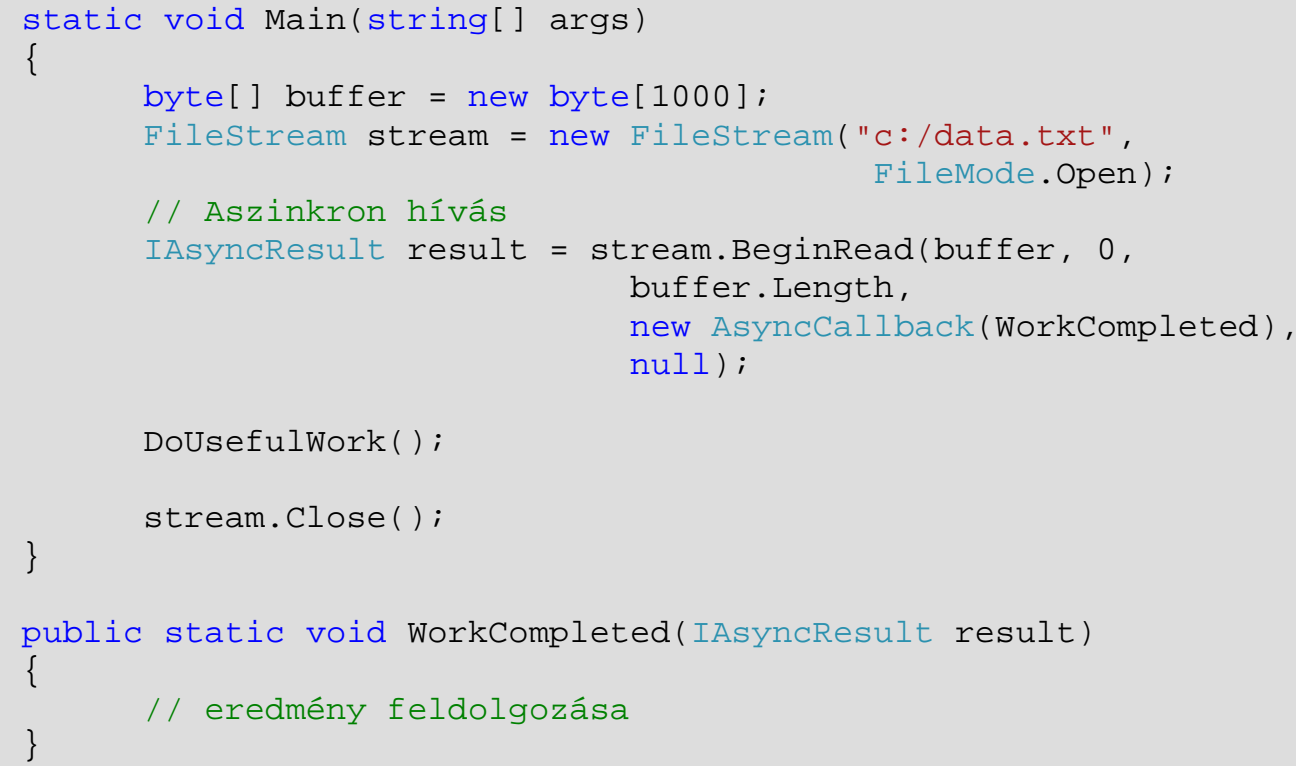

24. ábra-Callback modell

\subsection{Kivételkezelés aszinkron esetben}

Az aszinkron hívás esetében a kivétel nem a bekövetkezés időpontjában és helyén dobódik, hanem az EndX metódus hívásakor, tehát a kivételeket ekkor tudjuk elkapni és kezelni.

Az EndX metódust feltétlenül try blokkban kell elhelyezni, ugyanis kivételt dobhat. Tekintsük az előző példában szemléltetett Callback modellt. A kivételkezelést az aszinkron művelet befejezésekor meghívandó metódusban kell elhelyezni, ha ott szeretnénk az eredményt feldolgozni. 


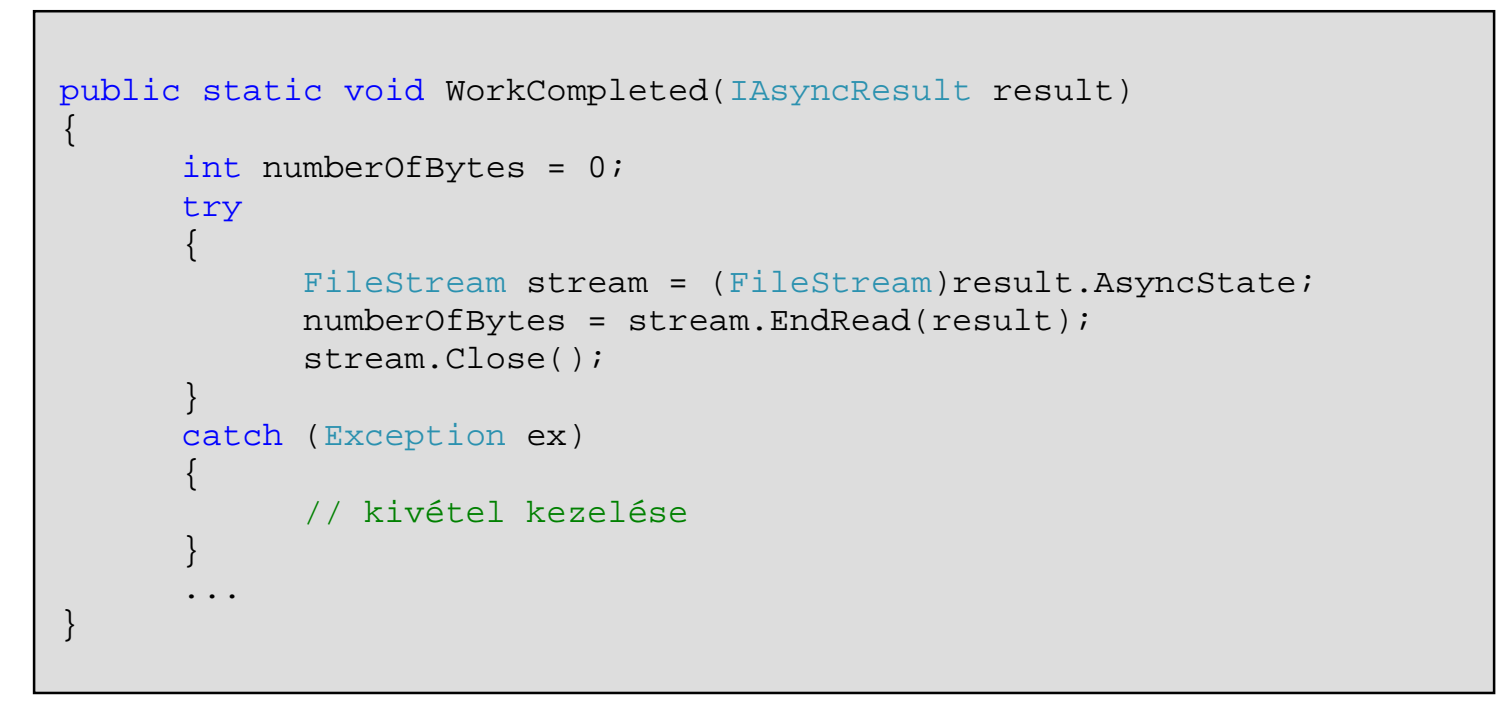

25. ábra-Kivételkezelés

\subsection{Szinkron és aszinkron WCF metódusok}

A WCF service metódusoknál mindenképpen használjunk aszinkron modellt, ha az alkalmazásunk egyszálas vagy a metódus olyan müveleteket végez, melyek blokkolóan hatnak az adott szálra. Ilyenek például az IO műveletek.

A WCF kliens kétféle aszinkron hívási modellt támogat. Az egyik az előző fejezetekben ismertetett System.IAsyncResult objektumot használja, míg a másik esemény alapú.

Ahhoz, hogy egy service metódust aszinkronná tegyünk, a BeginX metódusra az OperationContractAttribute attribútumot kell alkalmaznunk és az AsyncPattern property-jét truera kell állítani: 


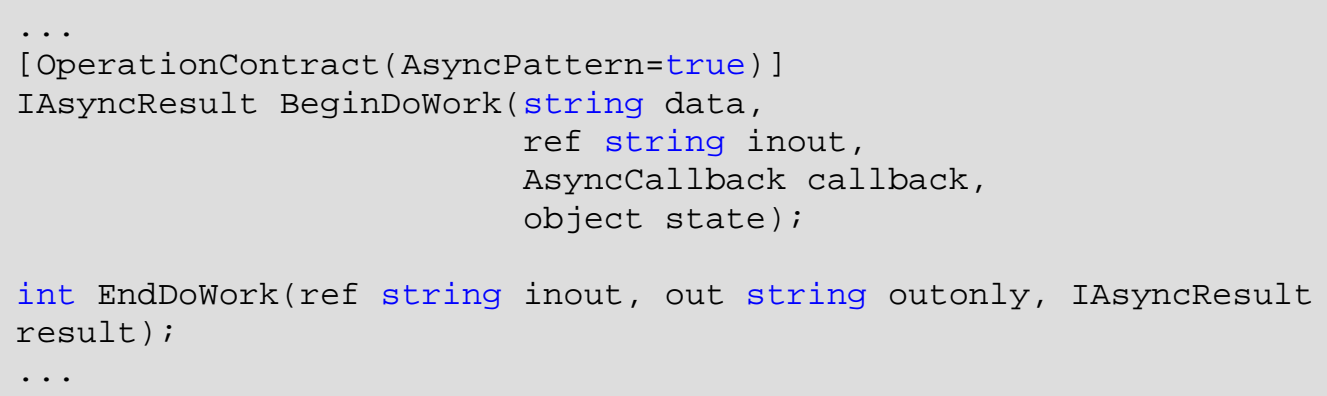

26. ábra-Aszinkron service metódus implementációja

Egy WCF alkalmazásban egy service metódus lehet szinkron és aszinkron is anélkül, hogy ez megkövetelné a klienstöl, hogy hogyan hívja. Tehát egy szinkron metódust meg lehet hívni aszinkron módon és egy aszinkron metódust szinkron módon.

A kliens kód generálásánál az svcutil.exe programnak megadhatjuk, hogy generáljon aszinkron és szinkron infrastruktúrát a szolgáltatáshoz. Ekkor a szinkron metódusoknak aszinkron változata is lesz és fordítva, illetve az esemény alapú aszinkron hívást is megvalósíthatjuk. Példaként tekintsük a következő szolgáltatás implementációt:

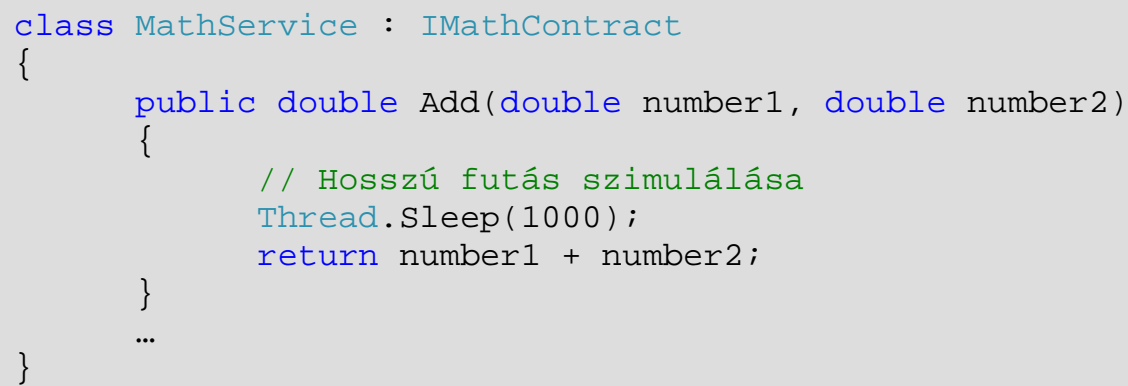

27. ábra-Service metódus implementációja

Az implementációban egy szinkron metódust láthatunk, amelyben a hívó szálat blokkoljuk 1 másodpercig, ezzel szimulálva a hosszú futási időt. Szinkron hívás esetén programunk blokkolt állapotba kerül, ami hosszú válaszidőt eredményez, ezért hívjuk meg aszinkron módon. 
Ehhez hívjuk segítségül az svcutil.exe programot és futtassuk a következő módon:

svcutil <wsdl_cím> /async /tcv:Version35

A /async kapcsoló hatására a program generálja nekünk a metódusok szinkron és aszinkron változatát, valamint a megfelelő event-eket. Nézzük meg a kliens oldalt:

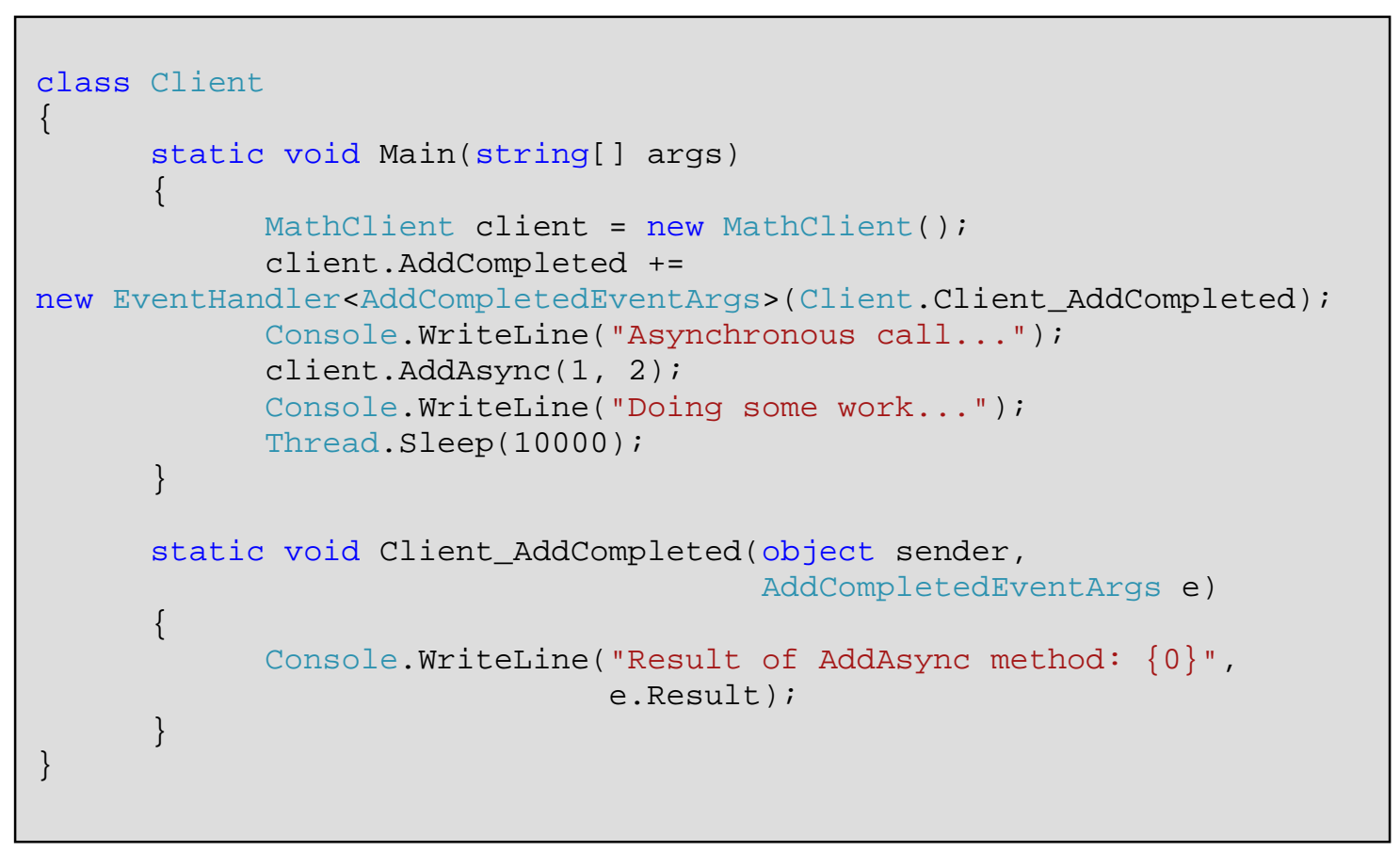

28. ábra-Aszinkron hívás a kliens oldalon

A kliens oldalon meghívtuk az Add metódus generált aszinkron változatát, majd kiírattunk a konzolra, ezzel is szimulálva egyéb utasítások végrehajtását, a szintén generált AddCompleted eseményhez megadott eseménykezelő metódus pedig megjeleníti az eredményt, amint az aszinkron hívás visszatért. 
A konzolon a várt eredmény jelenik meg:

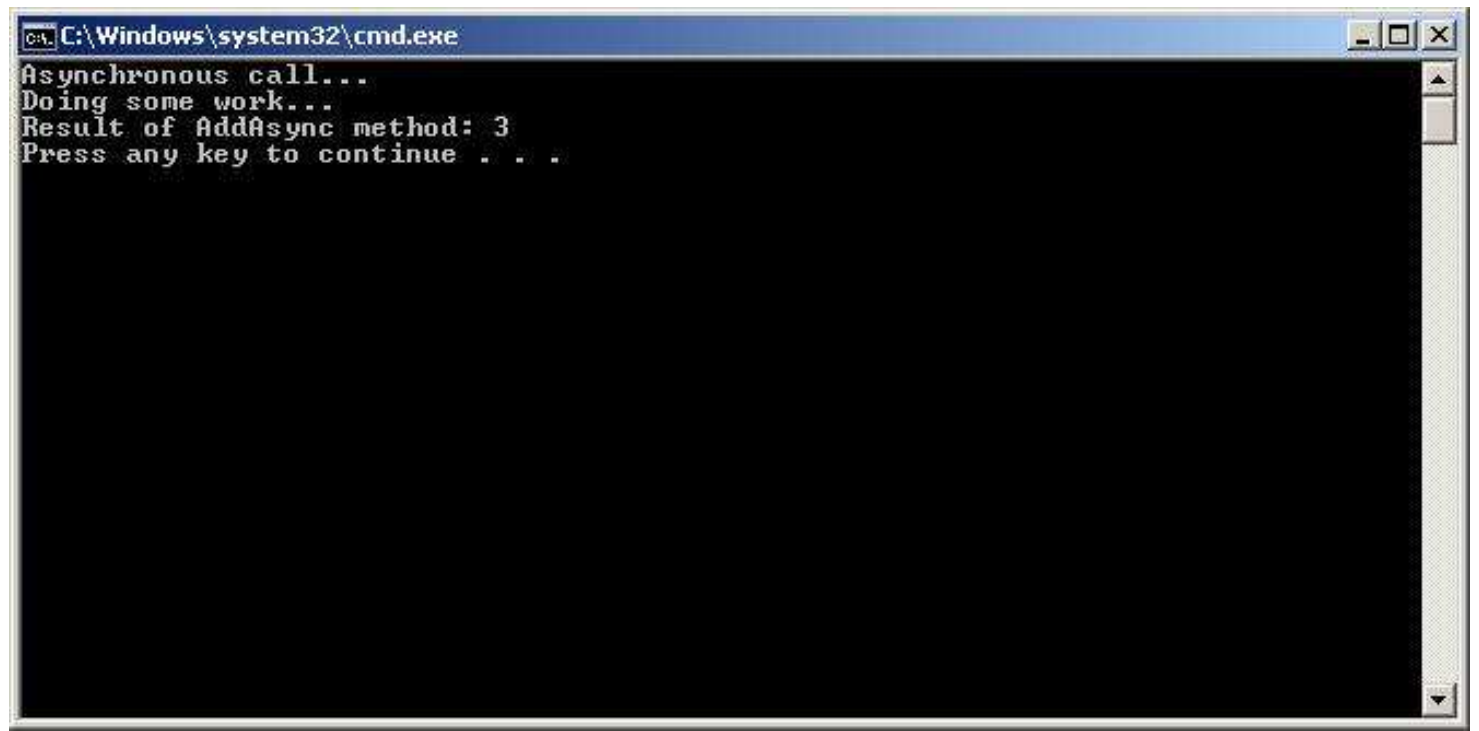

29. ábra - Aszinkron hívás eredménye a konzolon 


\section{Munkamenetek}

A Windows Communication Foundation munkamenete üzenetek egy csoportját egy adott párbeszéd részévé teszi, azaz lehetőség van egy munkameneten belül állapotmenedzsmentre, adatok megosztására, illetve a munkamenetet inicializáló és lezáró műveletek megadására.

A WCF munkamenetek fö jellemzői:

- A hívó alkalmazás inicializálja és zárja le explicit módon.

- Nincs a WCF munkameneteknek fenntartott általános tárolóhely.

- A munkamenet alatt kézbesített üzenetek az érkezés sorrendjében kerülnek feldolgozásra.

A ServiceContractAttribute attribútum SessionMode property-je segítségével beállíthatjuk, hogy az adott service contract megköveteli, megengedi vagy tiltja a munkamenet alapú binding-okat. A lehetséges értékek a System.ServiceModel.SessionMode enumeráció értékei lehetnek:

- Allowed: A service contract támogatja a munkameneteket, ha a beérkezö binding is támogatja.

- Required: A service contract megköveteli a munkameneteket támogató binding-ot. Ha nincs, akkor kivétel váltódik ki.

- NotAllowed: A service contract nem támogat olyan binding-ot, amely munkamenetet tud inicializálni.

Ez a beállítás csak a binding munkamenettel kapcsolatos tulajdonságára ad megszorítást, egyéb tulajdonságaira (például transport, security, stb.) nem. Ha a SessionMode property értéke és a binding között nincs összefüggés, akkor kivétel váltódik ki. 
Ha a service contract-ot úgy állítottuk be, hogy megköveteljen (Required) vagy támogasson (Allowed) munkameneteket, akkor a service metódusokhoz megadhatjuk, hogy hívásukkal indítsanak-e, illetve lezárjanak-e munkamenetet.

Az inicializáló metódusokat meg kell hívni egy új munkamenet létrehozásához, a nem inicializáló metódusok hívását pedig meg kell, hogy előzze legalább egy inicializáló hívás.

Munkamenet indítását okozzák a következő hívások a kliens oldalon:

- A System.ServiceModel.ChannelFactory.CreateChannel metódus által visszaadott objektumon hívott $O p e n$ metódus.

- System.ServiceModel.ClientBase.Open metódus hívása az Svcutil.exe program által generált kliens osztály példányán.

- Inicializáló service metódus (alapértelmezésként minden service metódus inicializáló) hívása a kliens objektumon.

Munkamenet lezárását okozzák a következő hívások a kliens oldalon:

- A System.ServiceModel.ChannelFactory.CreateChannel metódus által visszaadott objektumon hívott Close metódus.

- System.ServiceModel.ClientBase.Close metódus hívása az Svcutil.exe program által generált kliens osztály példányán.

- Termináló service metódus hívása a kliens példányon.

A következő példában (forrás: http://msdn.microsoft.com/) egy olyan service contract-ot láthatunk, amely megköveteli a munkamenetek használatát. Láthatjuk, hogy az egyetlen inicializáló metódus a Clear, tehát az implementáció során az eredmény tárolására használt változót itt inicializálhatjuk (például nulla értéket adunk neki). Az Equals metódus termináló, azaz lezárja a munkamenetet. A további metódusok nem indítanak és nem zárnak le 
munkamenetet. Ez a szerkezet biztosítja, hogy egy munkamenet létrejöttekor és lezárásakor bizonyos feladatokat elvégezzen a szolgáltatás.

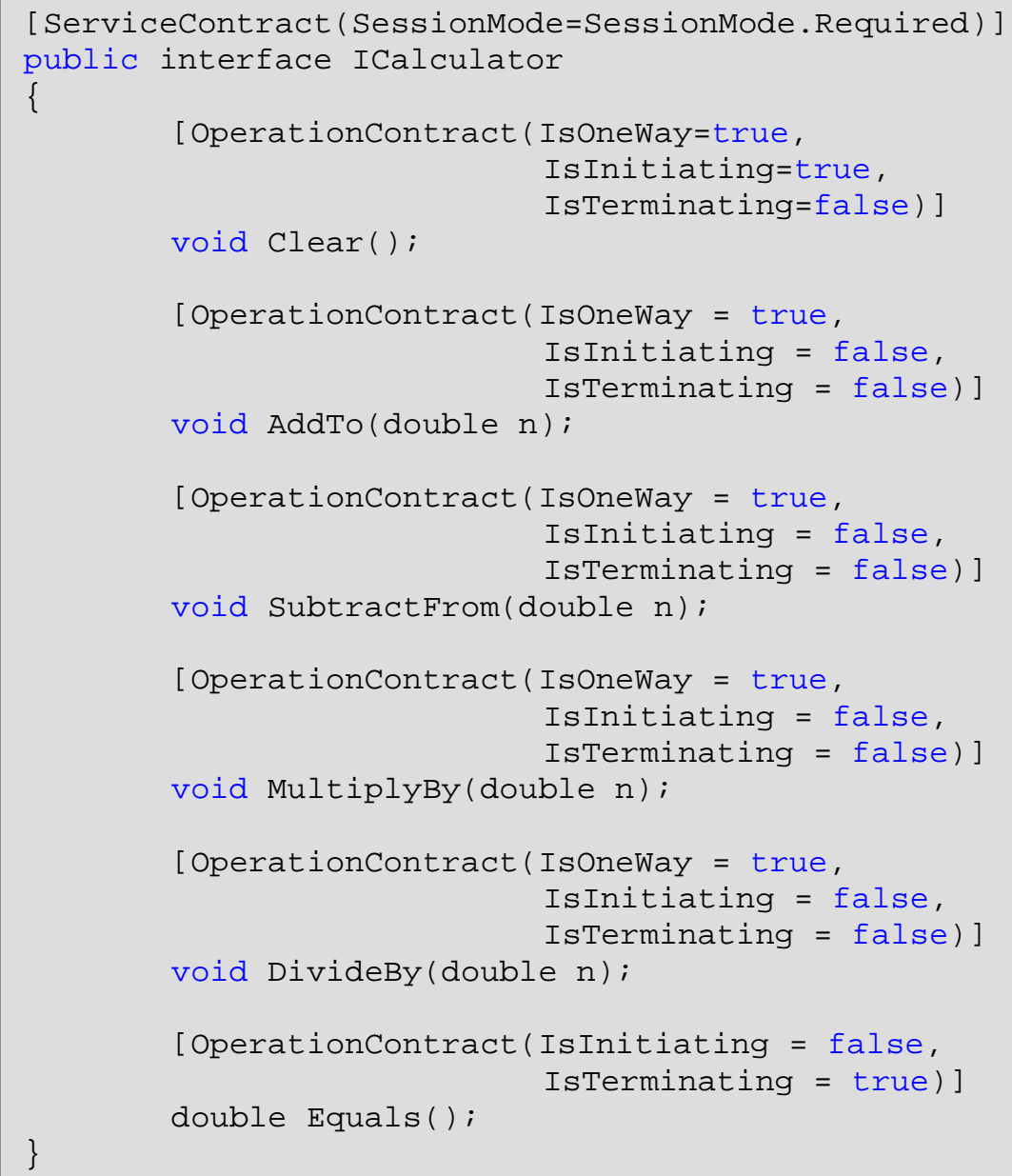

30. ábra-Munkamenetes tulajdonságok beállítása 


\section{Szolgáltatás példányok}

A System.ServiceModel.ServiceBehaviorAttribute attribútum InstanceContextMode property-je segítségével vezérelhetjük a szolgáltatás példányainak létrejöttét. A lehetséges értékeket a System.ServiceModel.InstanceContextMode enumeráció tartalmazza:

- PerCall : egy új szolgáltatás objektum jön létre minden egyes hívás elött.

- PerSession : egy új szolgáltatás objektum jön létre minden egyes munkamenetre.

- Single: egy szolgáltatás objektum jön létre az összes hívás kezelésére.

A következő példa forrása a http://msdn.microsoft.com/:

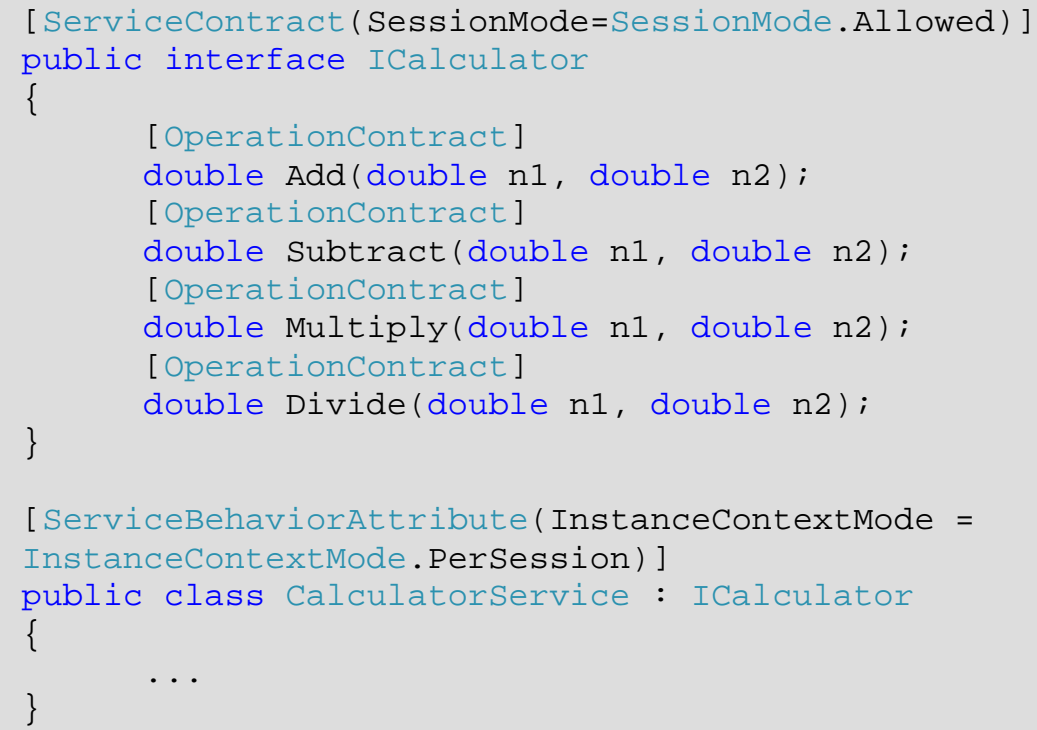

31. ábra - InstanceContextMode property beállítása

Ez a service contract támogatja a munkameneteket. A kliens oldal szimulálja a szolgáltatás metódusainak a folyamatos hívását. A végponthoz érkező hívások és a keletkezett példányok másodpercenkénti számát a következő ábra mutatja: 


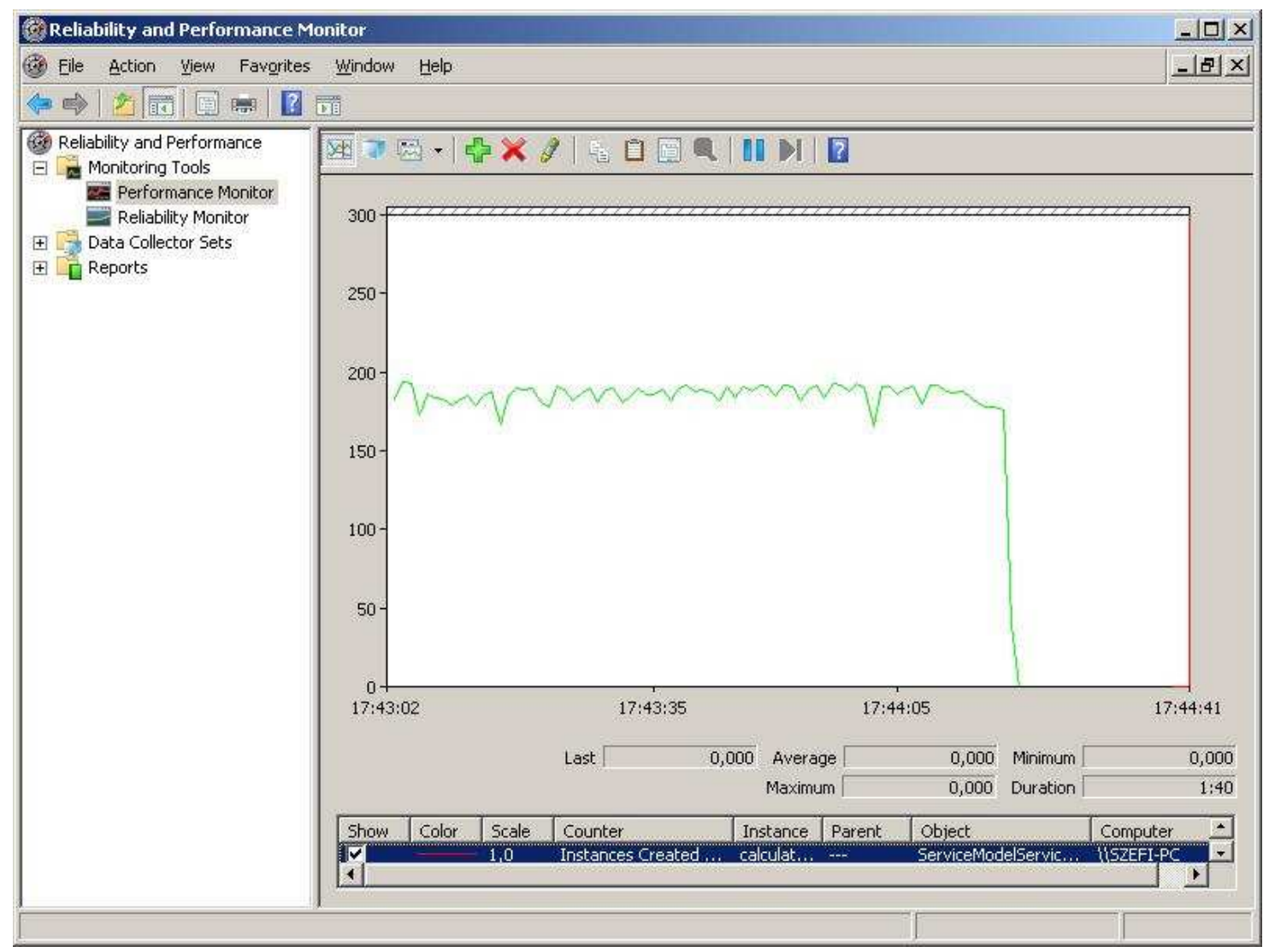

32. ábra - A végponthoz érkezö hívások és a keletkezett példányok másodpercenkénti száma

Amint az ábrán láthatjuk, másodpercenként körülbelül 180-190 service metódust hív a kliens, de mivel ez ugyanahhoz a munkamenethez tartozik, és az InstanceContextMode property értéke PerSession, nem keletkezik új példány. (Az ábrán a zöld görbe jelöli a meghívott service metódusok másodpercenkénti számát, a másodpercenként létrejött példányok száma pedig nulla, ezért annak a görbéje nem látható.)

Ha az InstanceContextMode property-nek PerCall értéket adunk, akkor minden service metódus hívása esetén egy új szolgáltatás példány jön létre. A következő ábra az előző példában szereplő teljesítményszámlálókat mutatja (A kliens változatlan, csak a service contract-on, illetve a generált kódban történt módosítás). 


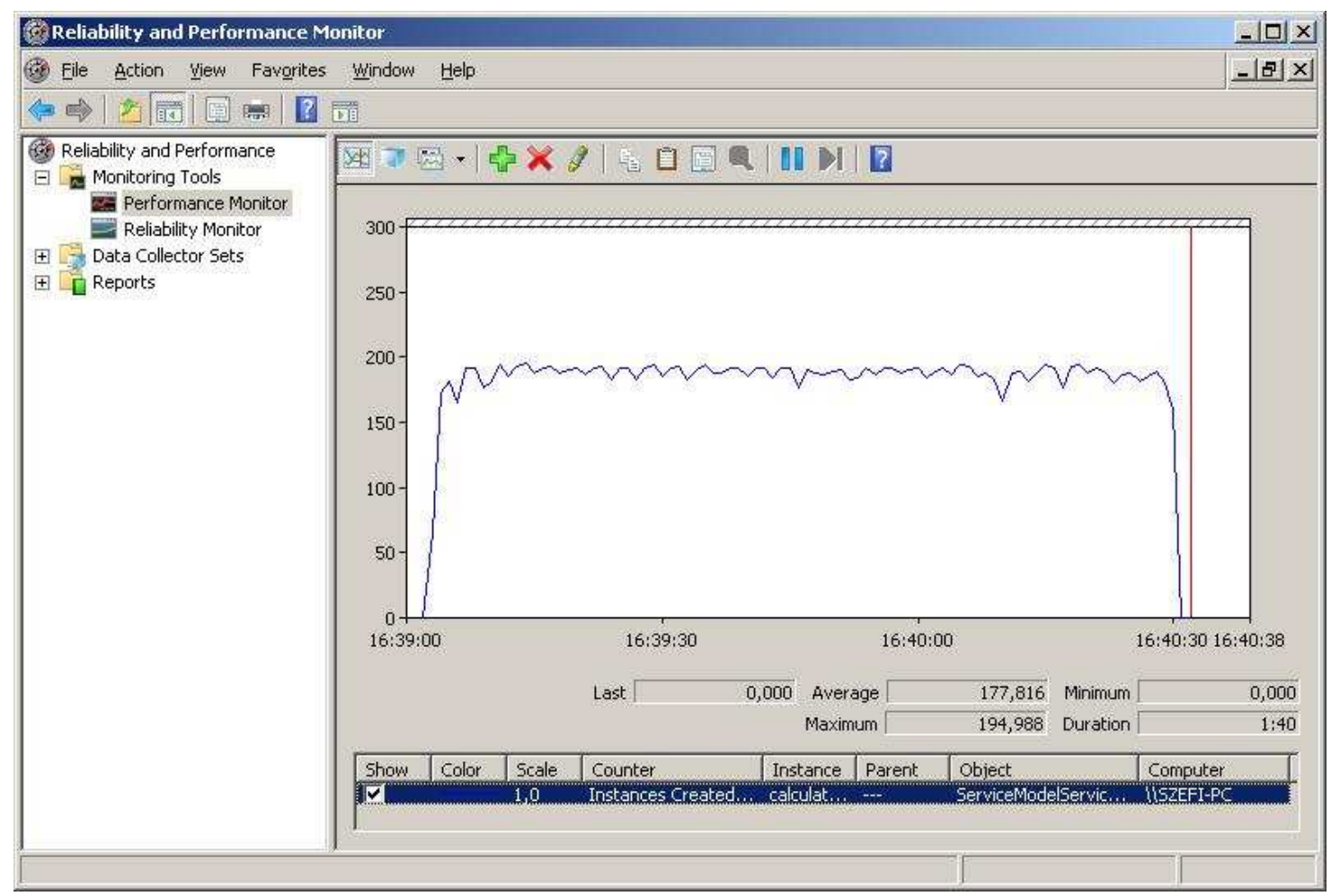

33. ábra - A végponthoz érkezö hívások és a keletkezett példányok másodpercenkénti száma

A hívott service metódusok számában természetesen nincs jelentős eltérés, de a képen kijelölt teljesítményszámláló (Instances Created Per Second) a 177,816 átlagot mutatja, ami jól szemlélteti, hogy minden hívás előtt új példány keletkezik. 


\section{Tranzakciók}

A tranzakció utasítások, müveletek oszthatatlan végrehajtási egysége, amely rendelkezik az ún. ACID tulajdonságokkal:

- Atomicity (atomosság): A tranzakcióban szereplő utasítások vagy teljes egészében végrehajtódnak és tartóssá (lásd: durability) válnak, vagy visszagörgetésre kerülnek és hatásuk elvész.

- Consistency (konzisztencia): Ez a tulajdonság garantálja, hogy egy tranzakció alatt bekövetkezett változások az egyik konzisztens állapotból egy másik konzisztens állapotba visznek.

- Isolation (elkülönülés): A tranzakció nem vehet figyelembe egy be nem fejezett tranzakció által végrehajtott változtatást. Úgy kell viselkednie, mintha az adott pillanatban ő lenne az egyetlen tranzakció.

- Durability (tartósság): Amikor egy tranzakció befejeződött, akkor a kifejtett hatása rögzül, nem állítható vissza a megelőző állapot.

A WCF esetén a következő 3 attribútum segítségével meghatározhatjuk egy szolgáltatás tranzakciós viselkedését:

\section{$\underline{\text { TransactionFlowAttribute attribútum }}$}

Meghatározza, hogy az adott metódus hogyan viszonyuljon a klienstől érkező tranzakciókhoz. Külső tényezőre ad megszorítást. Lehetséges értékek:

- Mandatory (kötelező)

- Allowed (engedélyezett)

- NotAllowed (nem engedélyezett) 
Megjegyzés: Lehetőség van ezen előírás magasabb szinten (végpont) történő megadására is (akár konfigurációs fájlban, akár kódban)

\section{$\underline{\text { ServiceBehaviorAttribute attribútum }}$}

Ez az attribútum a szolgáltatás belső müködését határozza meg. A tranzakciós viselkedésre vonatkozó property-jei a következők:

- TransactionAutoCompleteOnSessionClose

Ha a property értéke true (ebben az esetben természetesen a csatornának munkamenetesnek kell lennie) és a munkamenet szabályosan fejeződik be, akkor a folyamatban lévő tranzakciók befejeződnek. Ha a property értéke false vagy a munkamenet nem szabályosan fejeződik be (kezeletlen kivétel, hálózati probléma), akkor a nyitott tranzakciók visszagörgetésre kerülnek.

- ReleaseServiceInstanceOnTransactionComplete

Ezzel a property-vel megadhatjuk, hogy egy tranzakció befejezésével a szolgáltatás adott példánya felszabaduljon-e és egy új példány jöjjön létre vagy sem. Amennyiben új példány keletkezik minden tranzakció befejeződésekor, akkor a tranzakciók által létrejött állapotok nem maradnak meg.

- TransactionTimeout

Azt az intervallumot határozza meg, amely alatt egy tranzakciónak be kell fejeződnie, máskülönben meg lesz szakítva.

- TransactionIsolationLevel

A szolgáltatás tranzakcióknál használt izolációs szintjének megadására szolgál. 


\section{OperationBehaviorAttribute attribútum}

Ez az attribútum a service metódusok belső müködését határozza meg. Nincs hatással a WSDLre. A tranzakciós viselkedésre vonatkozó property-jei a következők:

\section{- TransactionScopeRequired}

A property értéke megadja, hogy az adott metódust egy aktív tranzakció hatáskörében

kell-e hívni. Amennyiben nincs külső tranzakciós hatáskör, akkor egy új tranzakció jön létre, közvetlenül a hívás előtt.

- TransactionAutoComplete

Megadja, hogy egy tranzakció automatikusan befejeződik-e, ha a metódus nem kezelt kivétel dobása nélkül visszatér.

Megjegyzés: Bizonyos tranzakciós tulajdonságok a konfigurációs fájlokban is beállíthatók.

Az alábbi példában egy metódus néhány tranzakciós tulajdonsága van megadva:

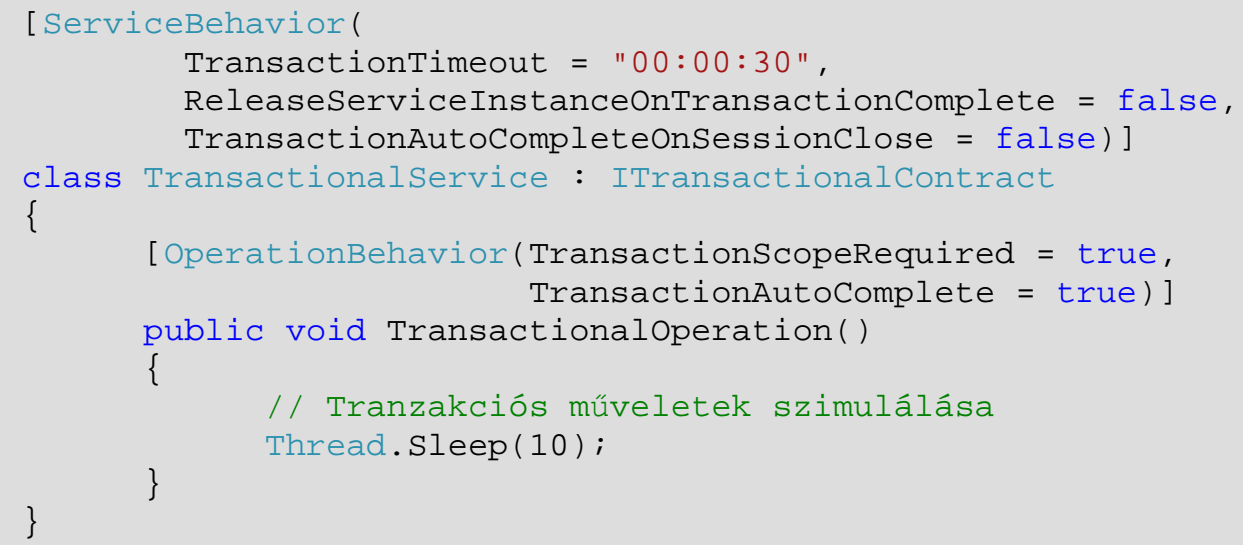

34. ábra - Szolgáltatás tranzakciós tulajdonságainak beállitása 
A kliens oldalon a metódust egy tranzakción belül hívjuk:

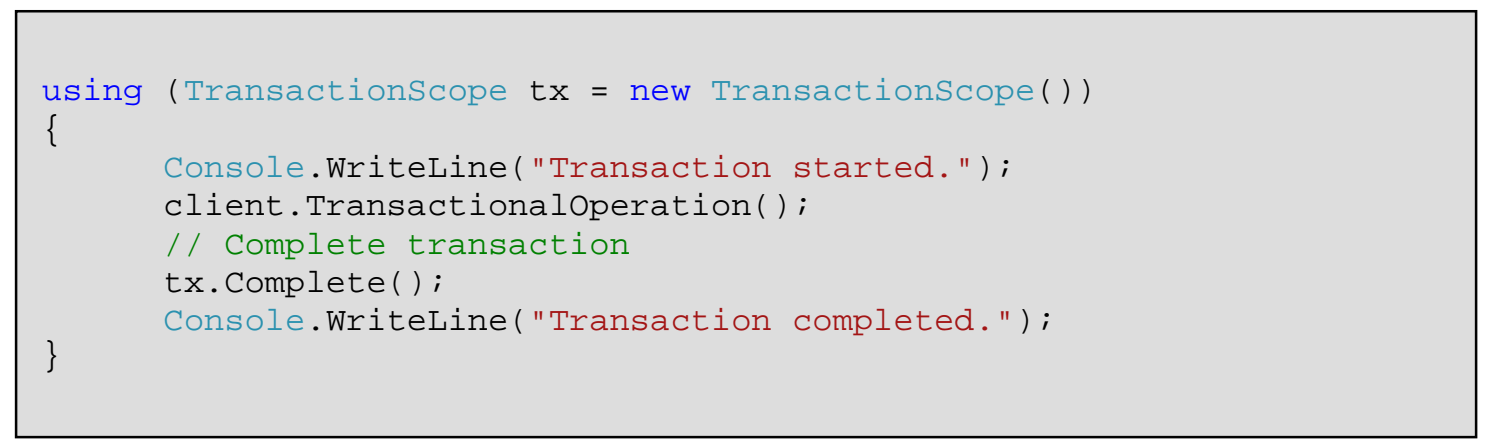

\section{5. ábra - Service metódus hívása tranzakció részeként}

A teljesítményszámlálók alkalmazásával a tranzakciós szolgáltatások működéséről diagnosztikai információkat kaphatunk. A következő ábrán egy szimulált környezet másodpercenkénti befejezett tranzakcióit láthatjuk.

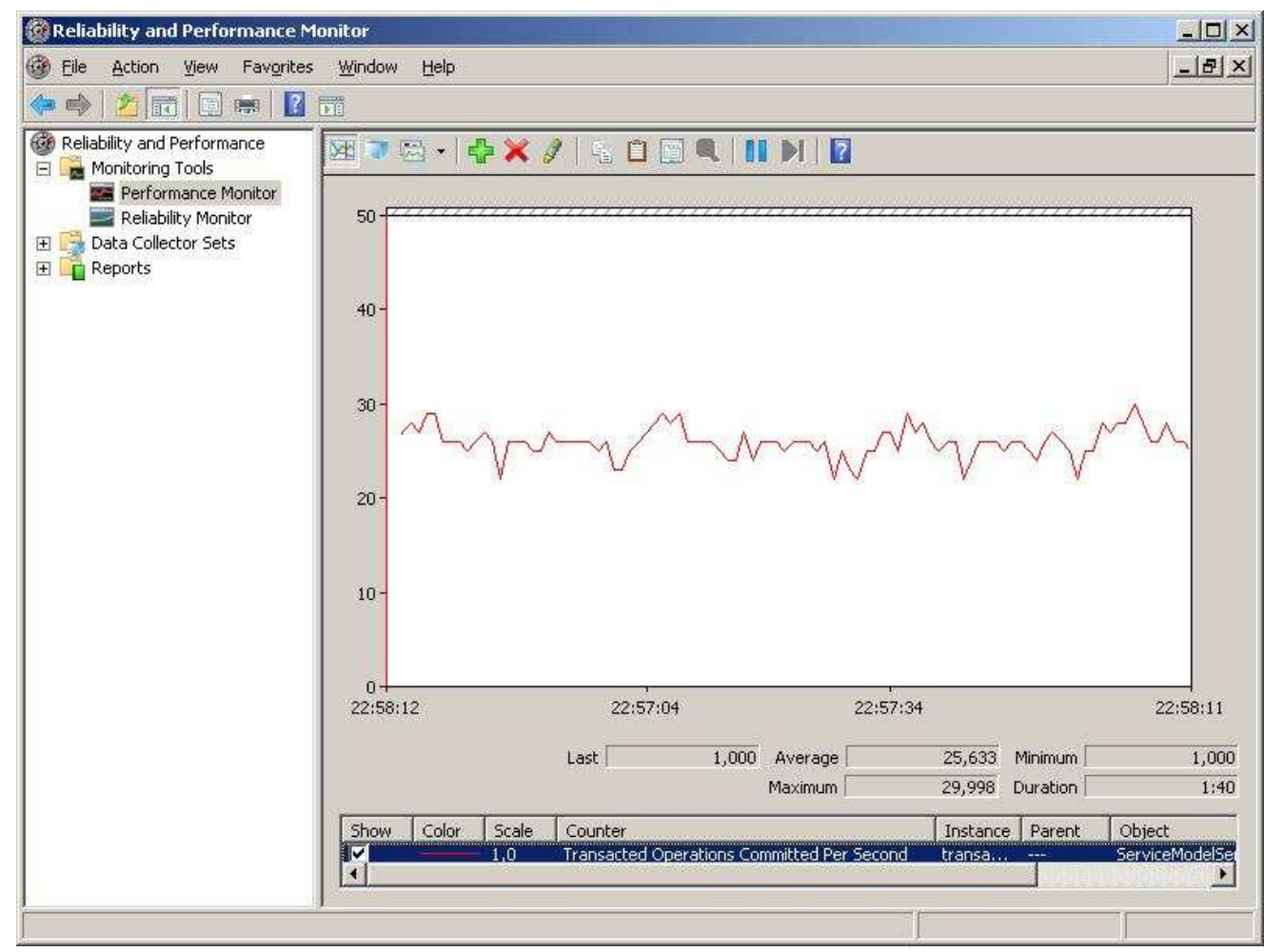

36. ábra-Másodpercenként befejezett tranzakciók számát mutató teljesítményszámláló 


\section{Kivételkezelés}

Kivételek természetesen a WCF szolgáltatások esetén is kiváltódhatnak, tehát fel kell készíteni az alkalmazást a kivételek kezelésére.

A SOAP alapú alkalmazásoknál a hibák információi SOAP hibaüzenet formájában kerülnek továbbításra. A SOAP hibák olyan üzenettípusok, melyek részei a service metódusok metaadatainak, ezáltal a kliens kezelni tudja azokat, robosztussá téve az alkalmazást. Természetesen ezek az üzenetek is XML formájában kerülnek továbbításra, ezért minden SOAP platformot használó kliens képes az információ kinyerésére.

A szerver kivételei SOAP hibává alakítva jutnak el a klienshez, a kliens pedig a megfelelő kivétellé alakítja. Duplex contract esetén a kliens is küldhet SOAP hibákat.

A SOAP hibák esetén megkülönböztetünk deklarált és nem deklarált hibát. Deklarált esetben a service metódust meg kell jelölni a System.ServiceModel.FaultContractAttribute attribútummal, és fel kell tüntetni a hibát reprezentáló típust. Természetesen több hiba is előfordulhat, az attribútum ismételt használatával azokat is jelezhetjük. Nem deklarált esetben hiányzik az attribútum és a WSDL sem tartalmaz róla információt. Fontos, hogy minden valószínűsíthető hibát jelezzünk, így a kliens fel tud készülni a megfelelő kezelésükre.

Megjegyzés: Csak olyan információkat küldjünk a kliensnek, amelyek feltétlenül szükségesek a hiba kezeléséhez.

Az alábbi ábrán egy fault contract megadása látható: 


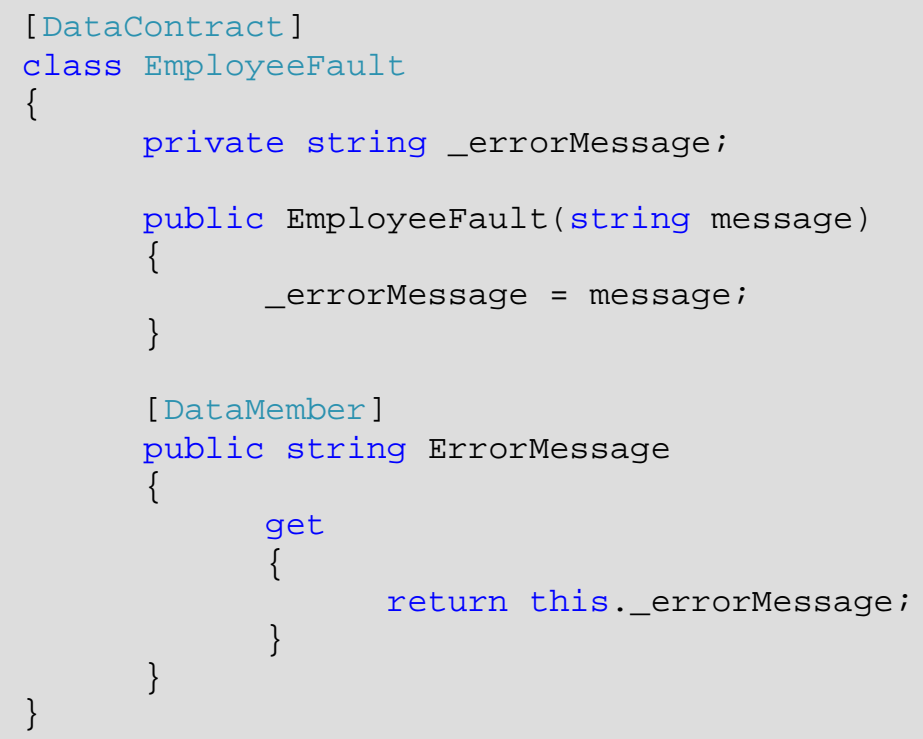

37. ábra-Fault contract megadása

A hiba információit tároló osztálynak szerializálhatónak kell lennie, hogy a csatornára kerülhessen, ezért meg van jelölve a DataContractAttribute attribútummal, szerializálandó adattagjai pedig a DataMemberAttribute attribútummal.

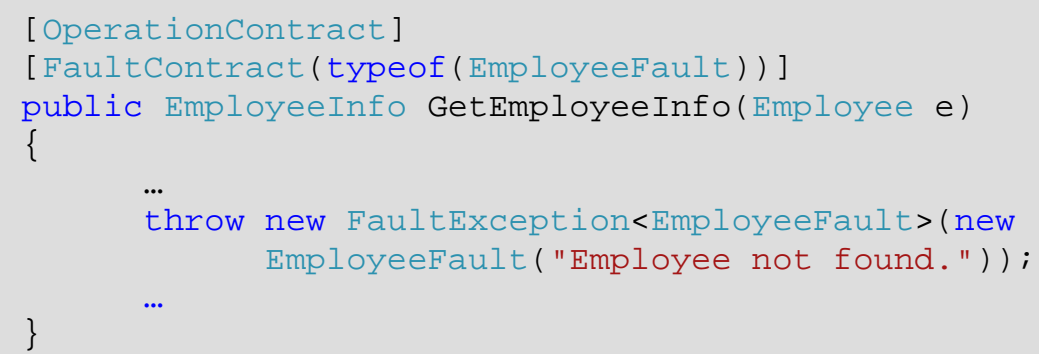

38. ábra - Kivétel kiváltása

A GetEmployeeInfo service metódusra alkalmazott FaultContractAttribute attribútum segítségével megadtuk, hogy a metódus az EmployeeFault deklarált hibát dobhatja. 
Ahhoz, hogy nem deklarált SOAP hibát küldhessünk, a nem generikus System.ServiceModel.FaultException osztály egy példányát kell dobnunk.

Most nézzük, hogy a kliens hogy reagálhat a felmerülő kivételekre. Fontos megemlíteni, hogy a FaultException-ön kívül System.ServiceModel.CommunicationException és System.TimeoutException is elöfordulhat. Ezeket is kezelni kell.

A catch ágak megadásánál lényeges a sorrend. A generikus FaultException osztály ősosztálya a FaultException, annak pedig a CommunicationException, ezért a leszármazott kivételeket kapjuk el először. Ha a legáltalánosabb kivétellel kezdenénk, akkor minden kivételt elkapnánk, és nem tudnánk reagálni a speciálisabb kivételekre.

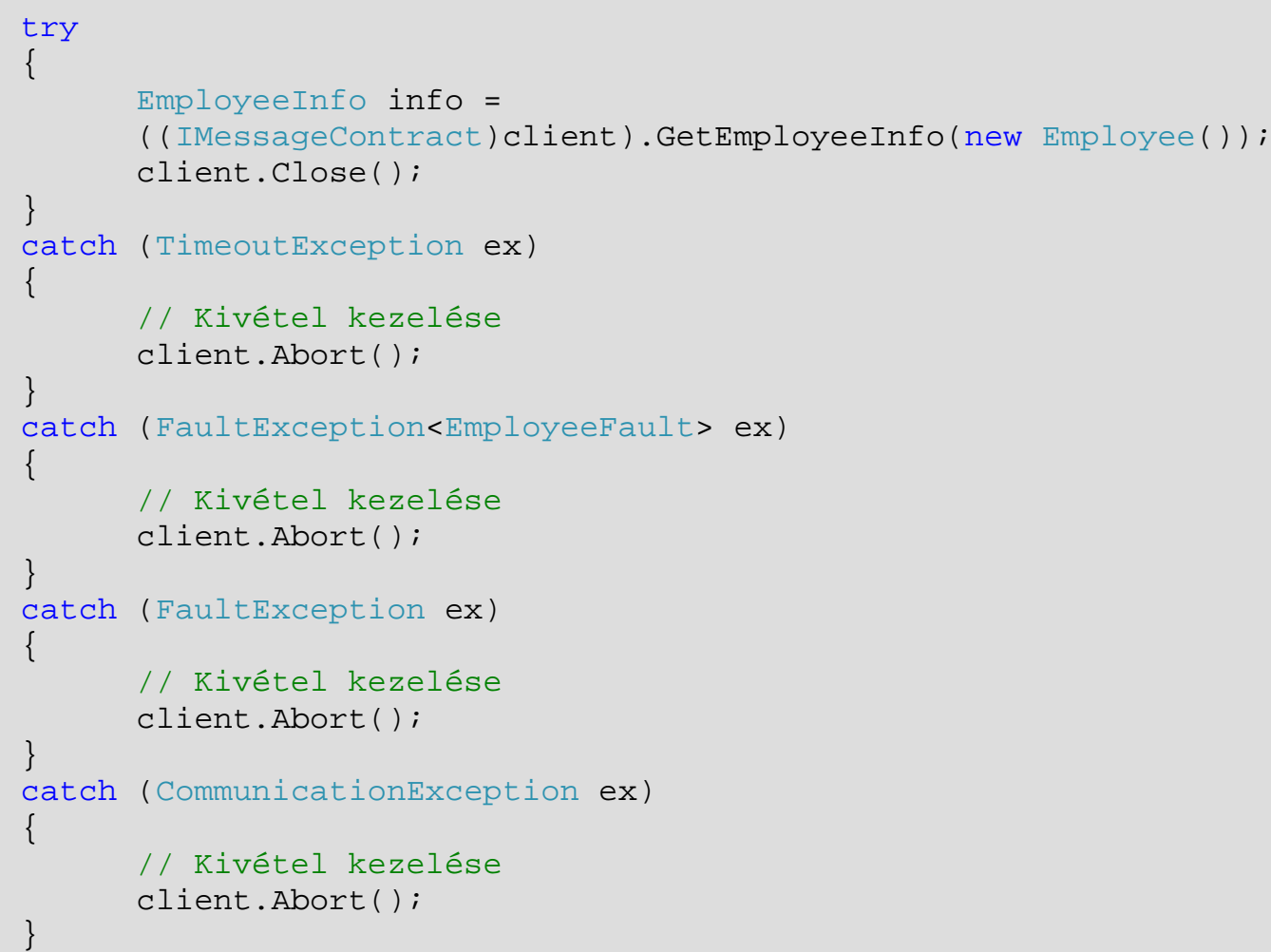

39. ábra-Catch ágak helyes sorrendje 
A service proxy létrehozásához nem javasolt a using utasítás használata, ugyanis az alábbi nem várt müködést eredményezheti:

- A using utasítás végén lefut az adott erőforrás Dispose metódusa, amely jelen esetben ekvivalens a Close metódus hívásával. A metódus hívása kivételt eredményezhet a kliens oldalon, tehát annak ellenére, hogy a using utasítás törzsében kivételkezelőt alkalmaztunk, kivétel váltódhat ki.

- Ha a using utasításban egy nem kezelt kivétel váltódik ki, akkor az elfedésre kerül, ha a Dispose metódus kivételt vált ki. 


\section{Diagnosztikai eszközök}

\subsection{Teljesítményszámlálók}

A teljesítményszámlálók információt nyújtanak az operációs rendszer, szolgáltatások, driver-ek, alkalmazások teljesítményéről. A Windows Communication Foundation teljesítményszámlálók széles körét alkalmazza, melyek segítségével felmérhetjük alkalmazásunk teljesítményét, szük keresztmetszeteket, rendelkezésre állást, sorbanállást, stb.

A teljesítményszámlálók alapértelmezésként nincsenek engedélyezve a WCF szolgáltatások számára. Engedélyezni az App.config alábbi bejegyzésével lehet:

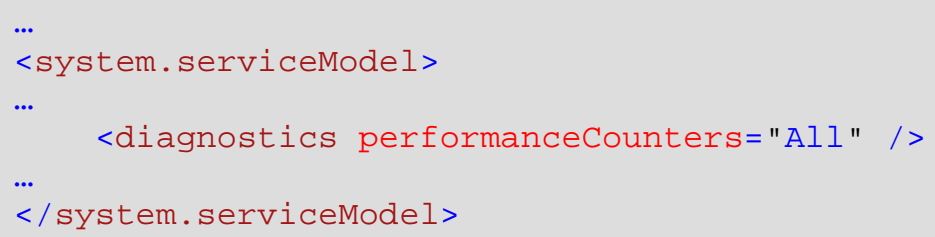

40. ábra - Teljesitményszámlálók engedélyezése konfigurációs fájl segítségével

A performanceCounters attribútum lehetséges értékei és ezek jelentése:

- All: Az összes WCF számláló kategória (ServiceModelService 3.0.0.0, ServiceModelEndpoint 3.0.0.0, ServiceModelOperation 3.0.0.0) engedélyezett.

- ServiceOnly: A ServiceModelService 3.0.0.0 kategória engedélyezett.

- Off: A három kategória egyike sem engedélyezett (alapértelmezés).

Ha az összes szolgáltatásra szeretnénk engedélyezni a teljesítményszámlálókat, akkor a Machine.config konfigurációs fájlban is elhelyezhetjük a fent említett bejegyzést. Mivel a 
Machine.config fájl bejegyzéseiből örököl az összes konfigurációs fájl, illetve annak bejegyzéseit terheli, nem kell az egyes szolgáltatások fájljaiban engedélyezni a teljesítményszámlálókat.

A számlálók által szolgáltatott adatok megtekinthetők a Windows operációs rendszer Performance Monitor (perfmon.exe) eszközével, melyet a vezérlöpult adminisztrációs eszközei között találunk meg.

A teljesítményszámlálók müködésének szemléltetésére létrehoztam egy WCF szolgáltatást 3 metódussal, melyeket 10 kliens hív.

A következő ábrák a szolgáltatás egyes metódusain történő hívások, illetve a szolgáltatáshoz érkező kérések másodpercenkénti számát mutatják.

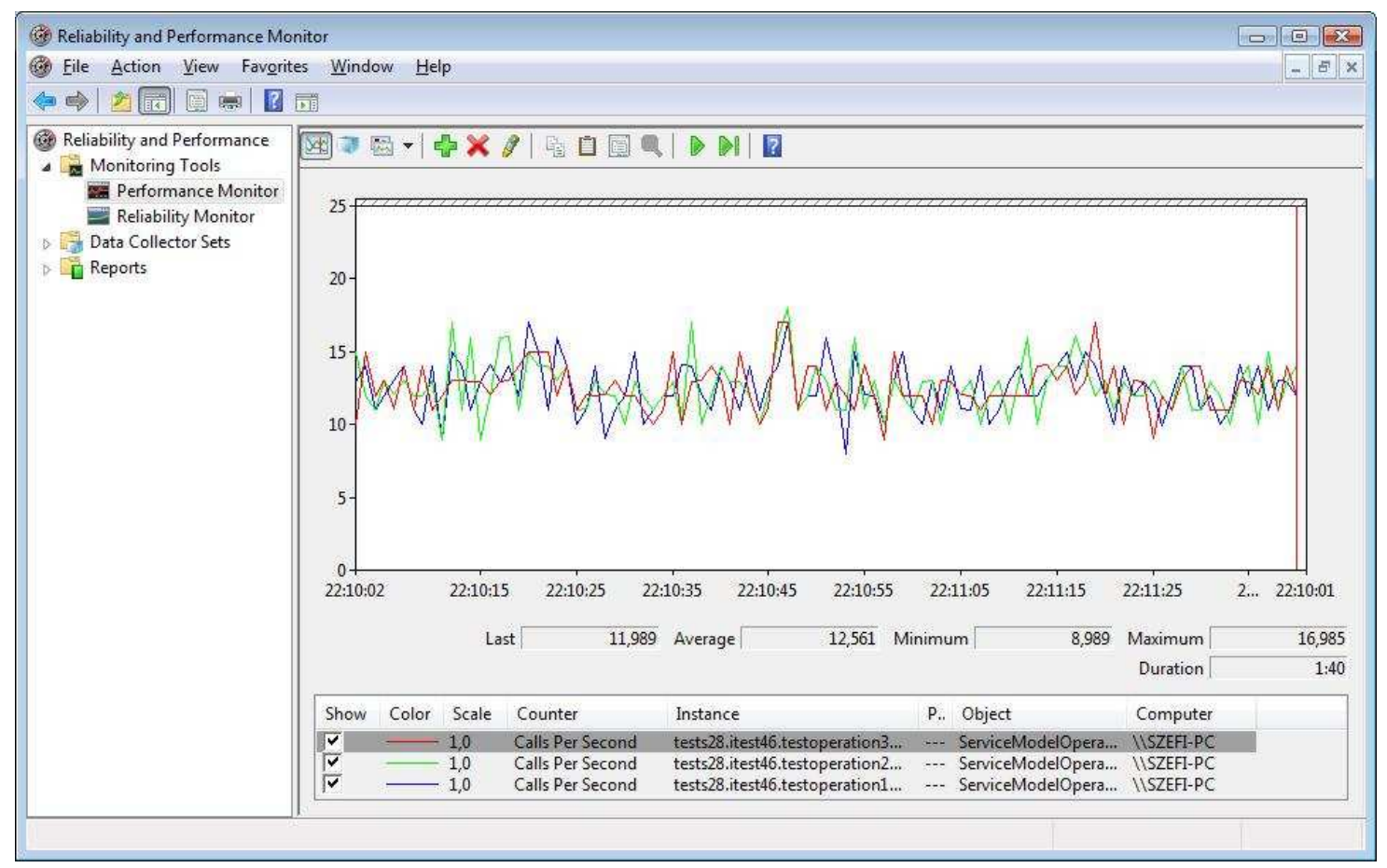

41. ábra - A szolgáltatás egyes metódusain történő hívások másodpercenkénti száma 


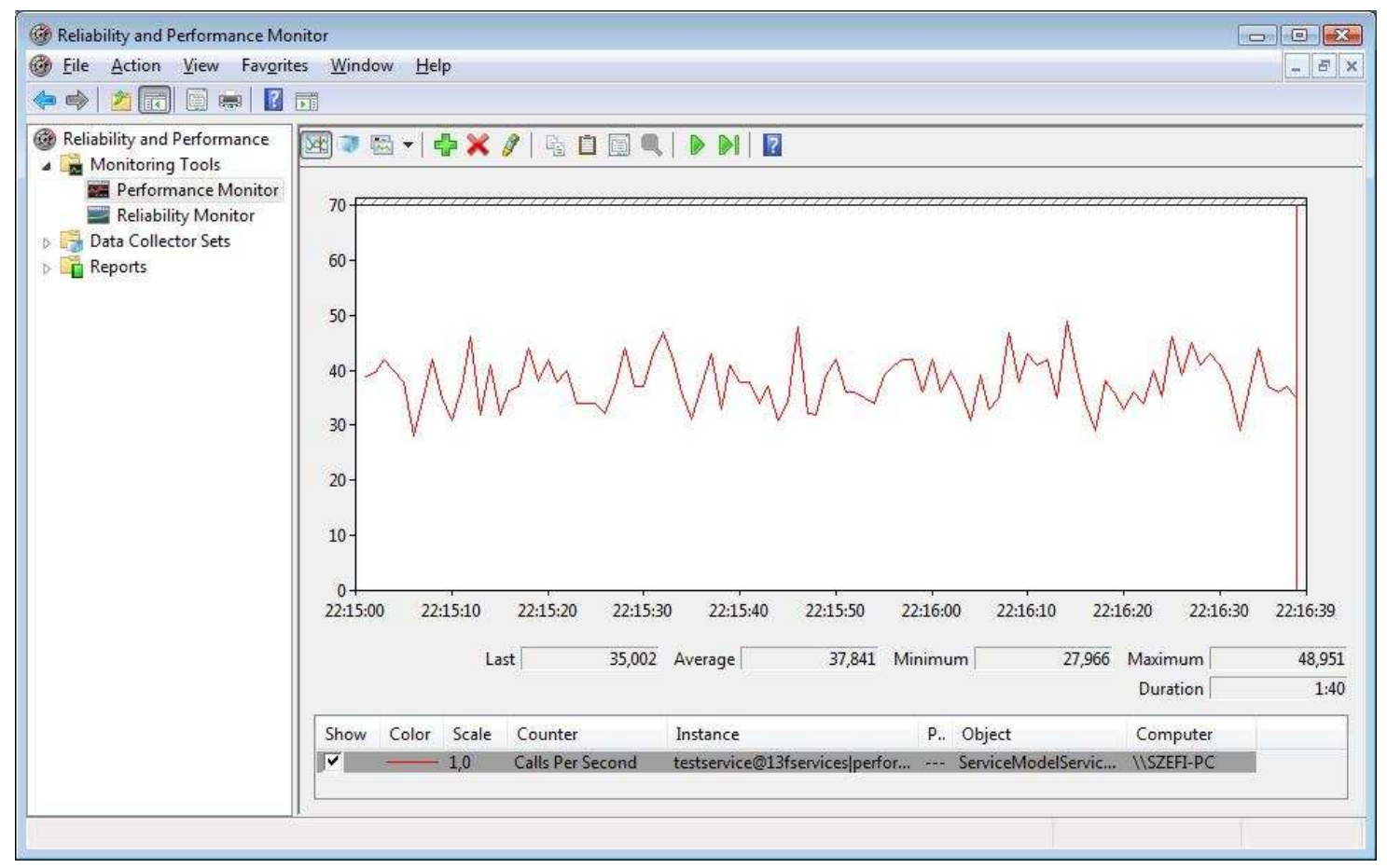

42. ábra - A szolgáltatáshoz érkezö kérések másodpercenkénti száma

\subsection{Nyomkövetés}

A nyomkövetés segítségével elemezhetjük, hogy miként müködik az alkalmazásunk, milyen kivételeket dob, milyen életciklus események következtek be, milyen hívások történtek. Erre támogatást nyújt a WCF. Ahhoz, hogy engedélyezzük a nyomkövetést, definiálnunk kell a forrást (trace source), a nyomkövetés szintjét és egy listener-t. Ha több forráshoz is ugyanazt a listener-t szeretnénk használni, akkor közös (shared) listener-ként is megadhatjuk. A Windows Communication Foundation minden egyes assembly-jéhez definiál egy forrást. Ezek közül a System.ServiceModel a legáltalánosabb.

A nyomkövetés szintjét a switchValue attribútummal állíthatjuk be.

Lehetséges értékei:

- Off 
- Critical

- Error

- Warning

- Information

- Verbose

- ActivityTracing

- All

melyekből többet is megadhatunk vesszővel elválasztva. A nyomkövetést engedélyezhetjük a kódban, de célszerü konfigurációs fájlban (web.config, app.config) beállítani, mert annak módosítása nem igényli az alkalmazás újrafordítását és a szerverre történő ismételt kihelyezését (deployment).

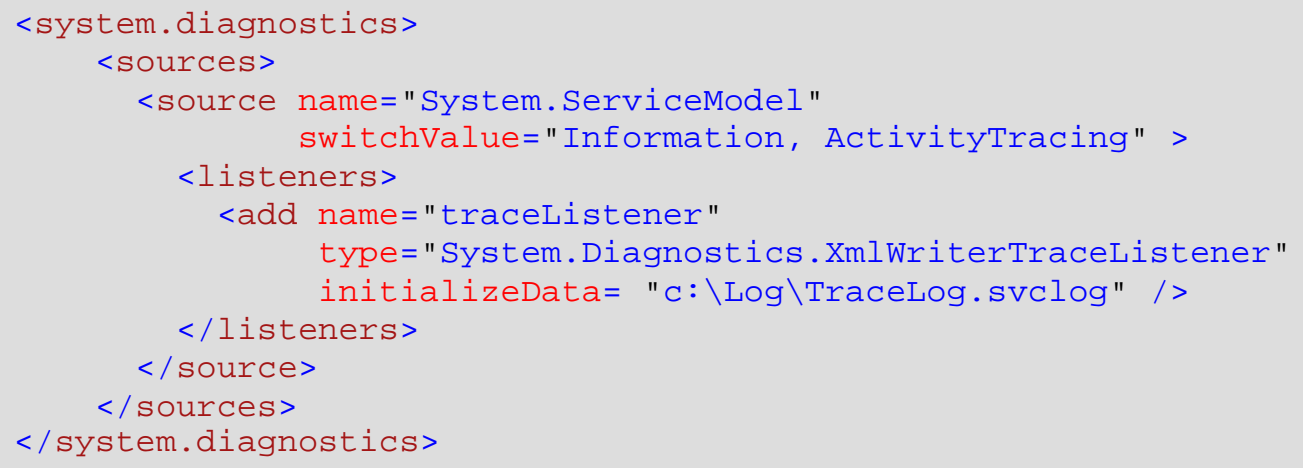

43. ábra - Nyomkövetés beállítása konfigurációs fájlban

A fenti konfigurációs beállítás a $c: \log \backslash$ TraceLog.svclog fájlba gyüjti a nyomkövetési információkat. Ezeket a bejegyzéseket megtekinthetjük a Service Trace Viewer programmal. 


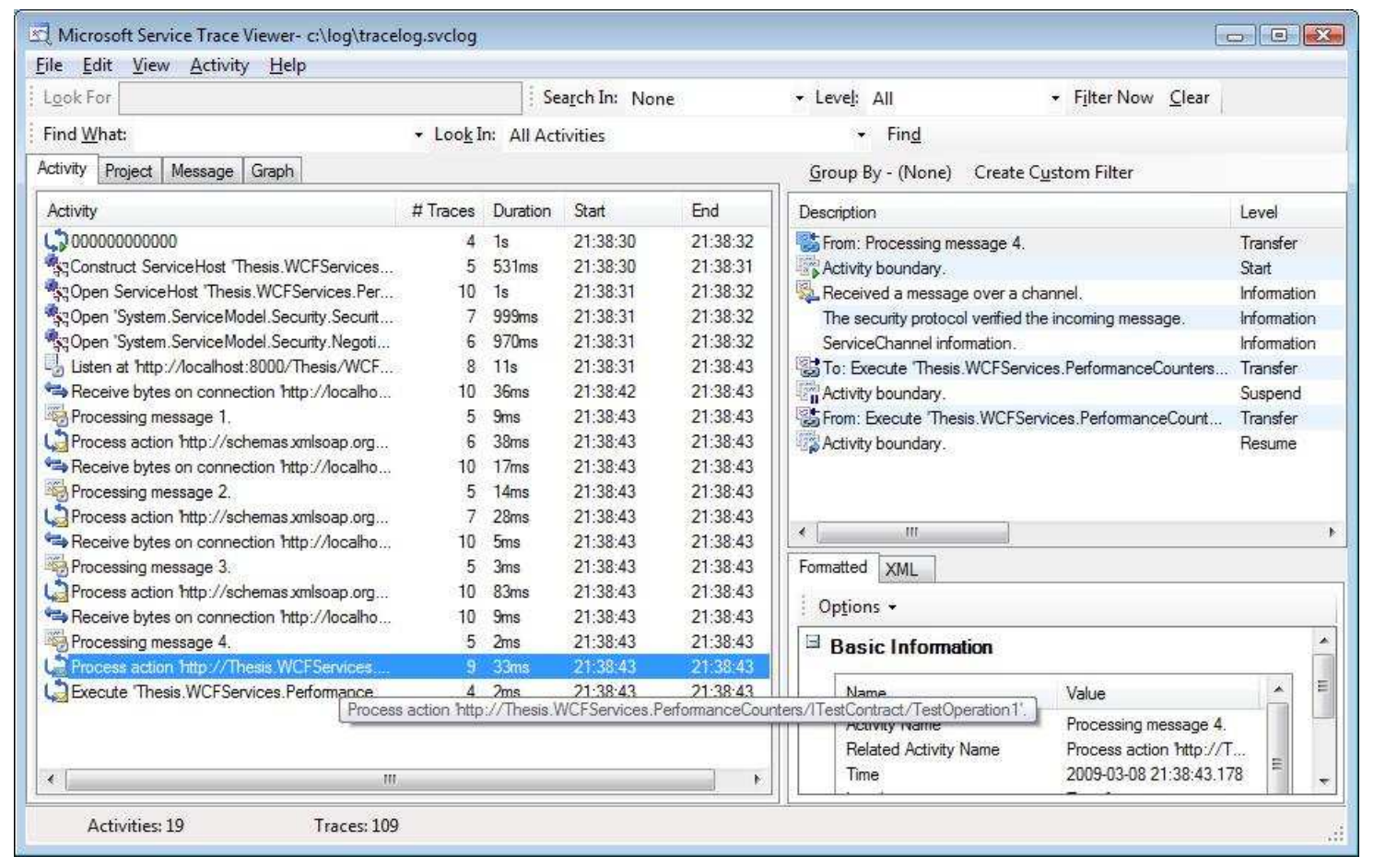

44. ábra - Tracing bejegyzések megtekintése 


\section{WCF és MSMQ}

Az elosztott rendszerek szempontjából fontos kérdés, hogy a szolgáltatás és a kliens között a kommunikáció direkt vagy sem. Direkt esetben, ha a hálózat nem müködik megfelelően (például egy kábel nincs csatlakozva), vagy csak nem indult el a szolgáltatás, akkor a kommunikáció nem lesz sikeres, fontos üzenetek veszhetnek el. Ezt a problémát megszüntethetjük, ha sor alapú kommunikációt valósítunk meg, azaz a szolgáltatás és a kliens(ek) között az üzenetek egy átmeneti tárolása jön létre. A sor természetesen független lehet a szolgáltatást és/vagy a klienst hosztoló géptől.

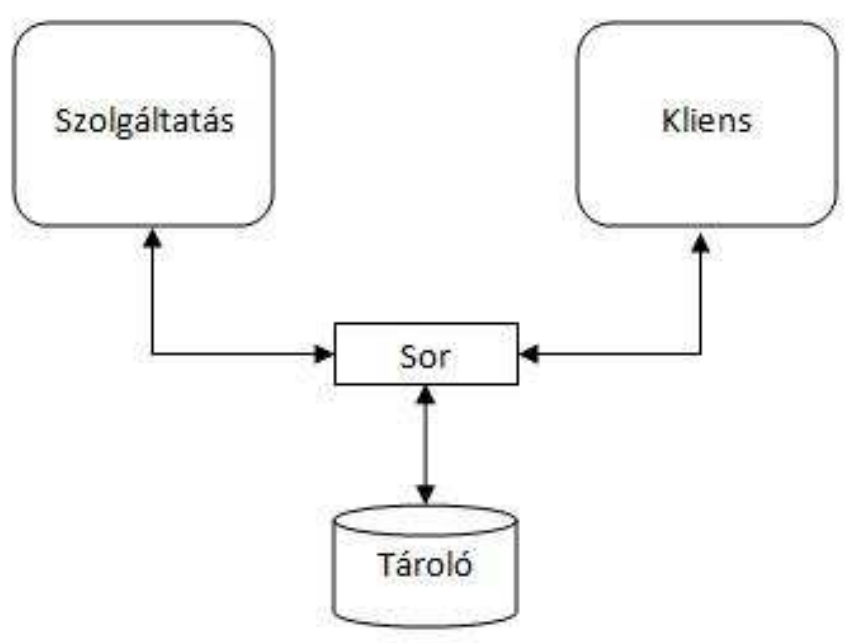

45. ábra - Sor alapú kommunikáció

Lehetöség van az üzeneteket egy tranzakció részeként a sorra küldeni, illetve onnan egy tranzakció részeként kiolvasni. Amennyiben a küldés során a tranzakció visszagörgetésre került, a sorban nem lesznek benne a tranzakció részeként küldött üzenetek. Ha a kiolvasás is tranzakciós és a tranzakció sikertelen, az üzenetek változatlanul a sorban maradnak. 
A WCF támogatja a Microsoft által implementált sor alapú, operációs rendszer szintű transzportot, az MSMQ-t (Microsoft Message Queuing). Ekkor a küldő alkalmazástól érkezö üzeneteket egy sor tárolja, majd továbbítja a fogadó félnek.

Az MSMQ használatának előnyei:

- Lazán csatolt alkalmazások jöhetnek létre, ugyanis a küldő és fogadó alkalmazások függetlenek attól, hogy a másik elérhető-e.

- A kommunikációt megbízhatóvá teszi még akkor is, ha a hálózat nem az. Ha a sorba bekerültek az üzenetek, akkor a fogadó alkalmazás fel tudja dolgozni azokat, ha elérhetővé válik.

- Egy szerver alkalmazás több példánya is olvashatja ugyanazt a sort, ezáltal a terhelés elosztható.

Ahhoz, hogy egy kliens alkalmazás üzenetet tudjon küldeni egy szolgáltatásnak, a célsort kell megcímeznie, és a szolgáltatásnak is az azon a címen található sort kell figyelnie.

A cím a következő mintára épül:

$$
\text { net.msmq://〈hosztnév >/[private/]<sornév> }
$$

A kommunikáció során a kliens nem kap garanciát arra, hogy a szolgáltatás mikor dolgozta, dolgozza fel a küldött üzeneteket, ezért használjunk one-way metódusokat a service contract-ban.

Az MSMQ használatához engedélyeznünk kell a megfelelő Windows komponenst a vezérlőpultban, majd a Computer Management programban létrehozhatjuk a használni kívánt sort. Ezt természetesen a kódban is megtehetjük, illetve vizsgálnunk is kell, hogy létezik-e. Amennyiben nem, akkor hozzuk létre.

Tekintsük a következő szolgáltatást, amely $M S M Q$-t használ a garantált kézbesítéshez: 


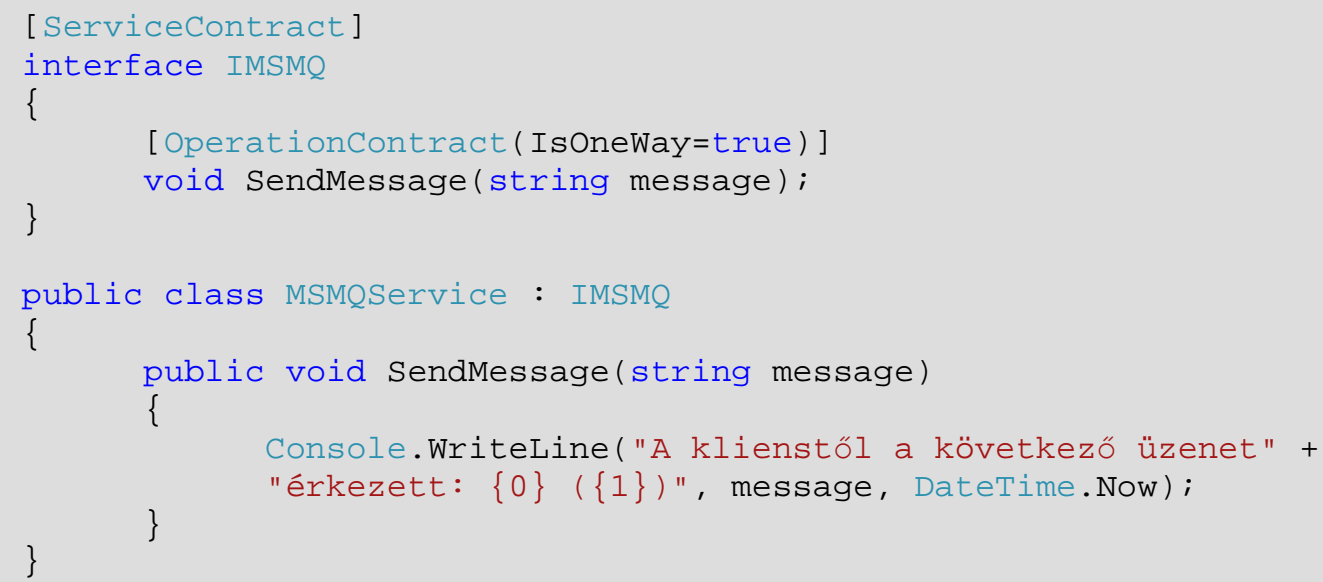

46. ábra - A service contract és implementációja

A SendMessage metódus egyirányú, mert a kliens nem várhatja meg, amíg a szolgáltatás megkapja az adott üzenetet (az is lehet, hogy nincs elindítva). A metódus hívása azt eredményezi, hogy a konzolon megjelenik a kliens által paraméterként átadott üzenet, illetve az aktuális időpont.

A hosztoláshoz szükséges kód és a hozzá tartozó konfigurációs fájl a következő ábrákon látható.

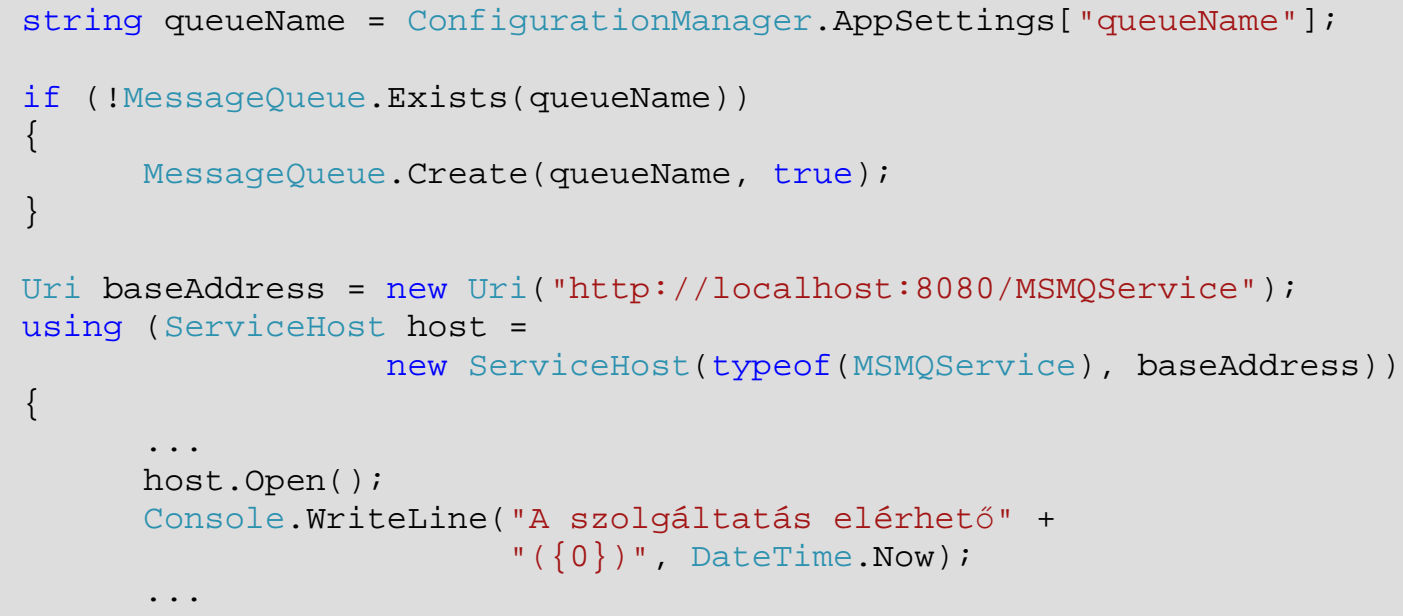

47. ábra-A hoszt kódja 
A sor nevét a konfigurációs fájlban célszerủ tárolni, ugyanis ez az adat változhat, és ebben az esetben nem kell az alkalmazást újrafordítani.

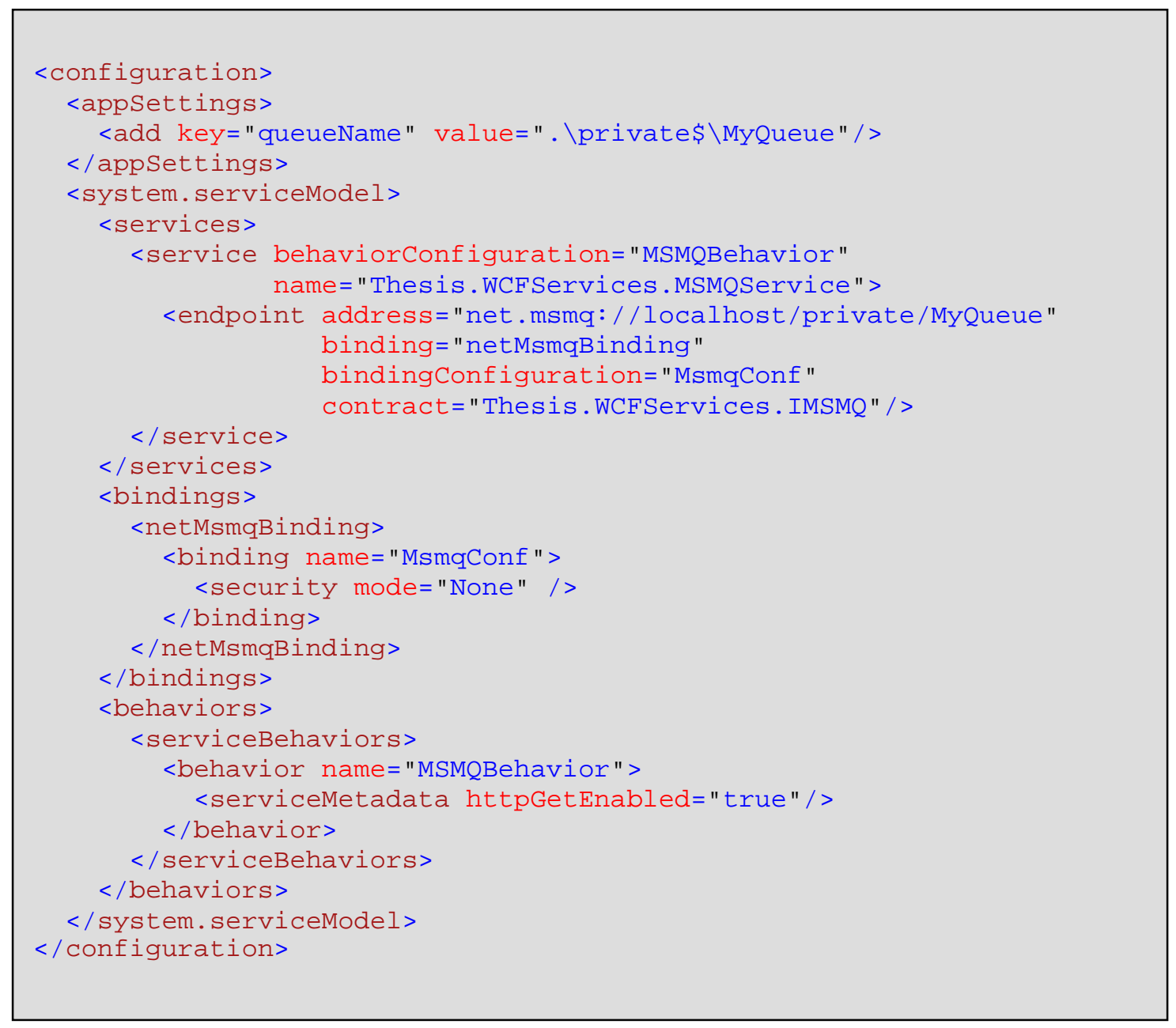

48. ábra-A konfigurációs fájl

A konfigurációs fájl appSettings bejegyzése tartalmazza a sor nevét. A binding-ot az $M S M Q$-t támogató netMsmqBinding-ra állítottam, illetve a fentebb megadott címzési sémát követtem.

A kliens számára a service proxy-t a ServiceModel Metadata Utility Tool segítségével lehet generálni. 


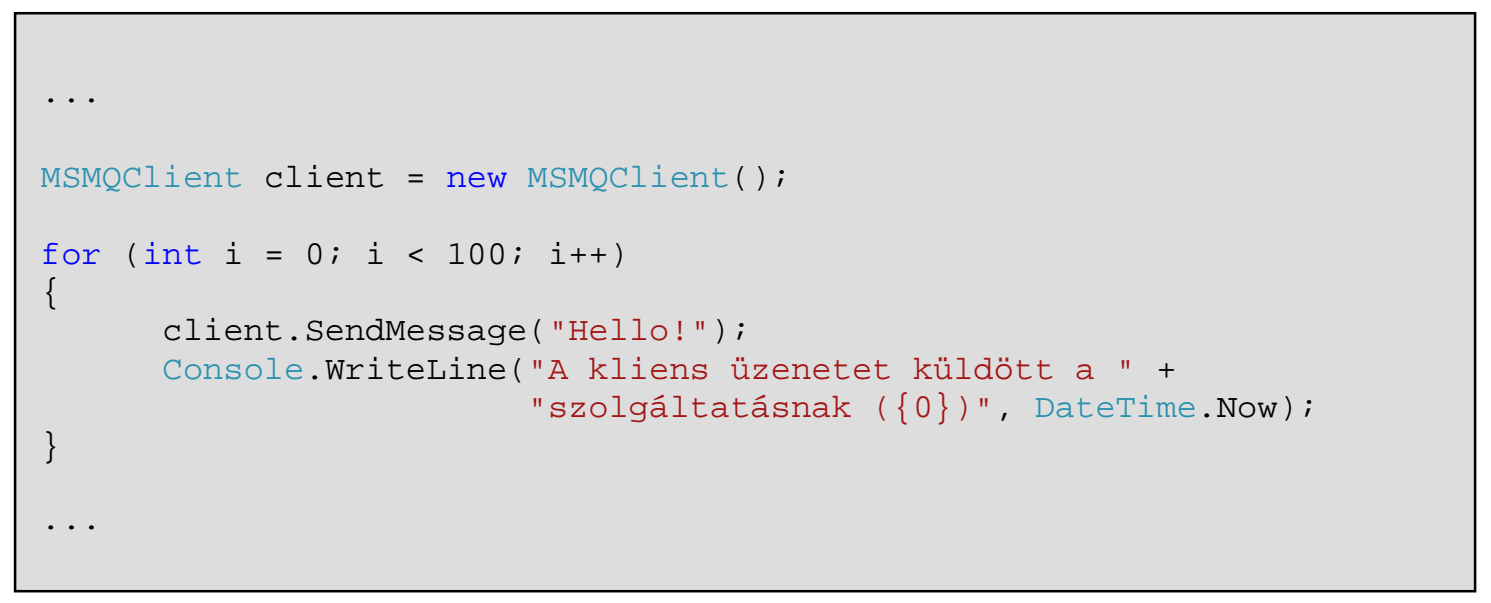

49. ábra-A kliens müködése

Látható, hogy a kliens százszor hívja meg a SendMessage metódust. Azért, hogy szemléltessem a sor használatát, nem indítottam el a szolgáltatást, de a klienst igen. A kliens oldali kimenet a következő:

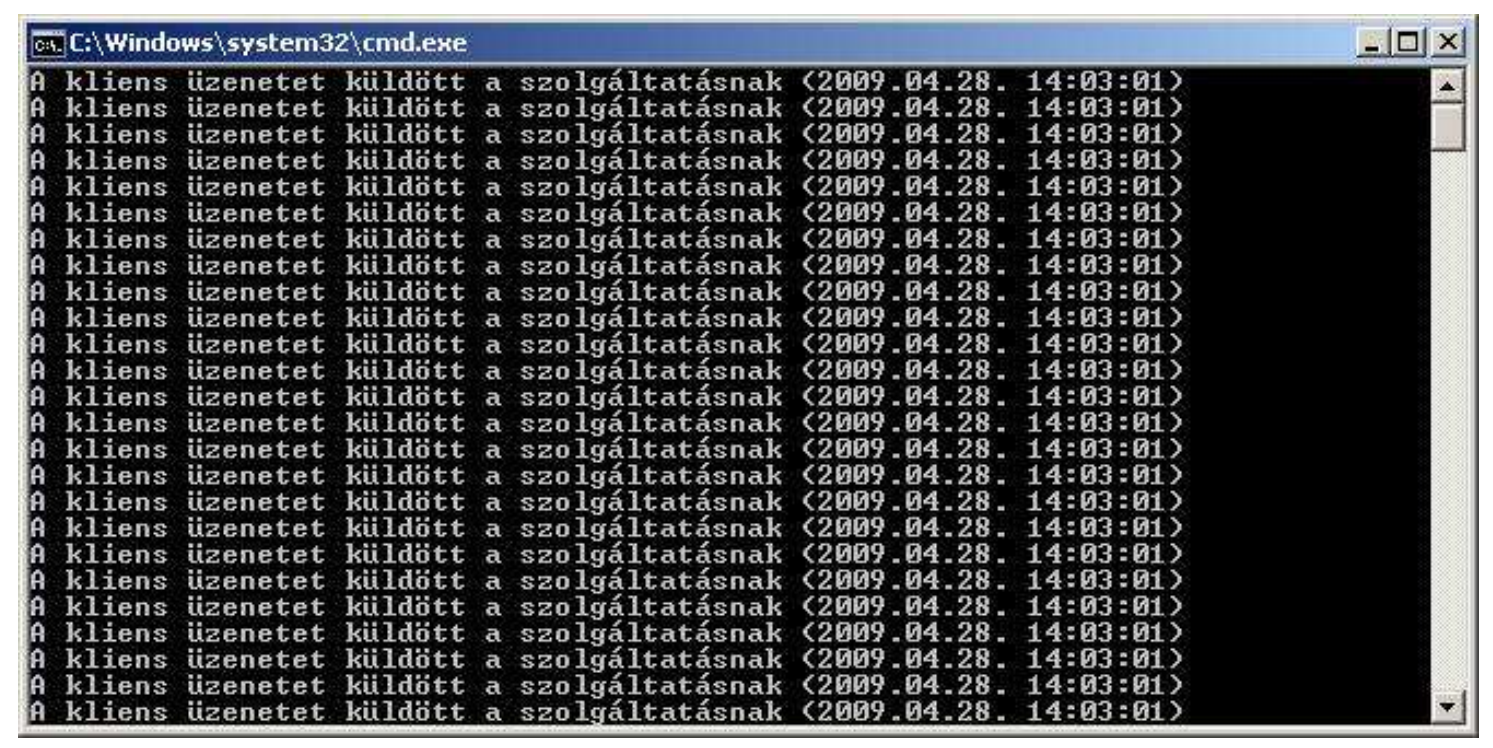

50. ábra-A kliens kimenete

A kliens hiba nélkül hívhatta a szolgáltatás által publikált metódusokat. A küldött üzeneteket a Computer Management program segítségével megtekinthetjük. Amíg a fogadó oldal nem kapja meg az üzenetet, addig az a sorban marad. 


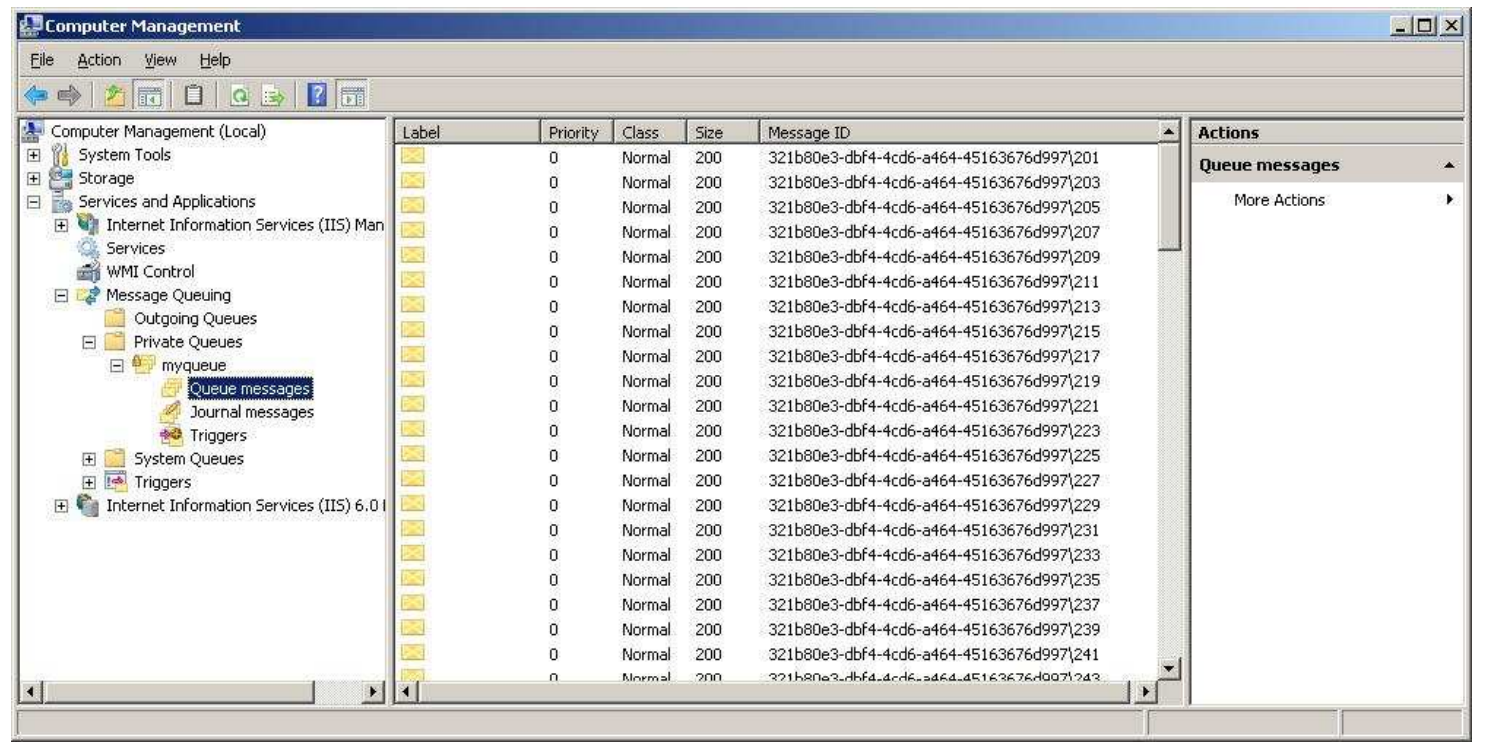

51. ábra-A sorban lévő üzenetek

Ha elindítjuk a szolgáltatást, akkor az feldolgozza a sorban lévő üzeneteket, és a következő kimenetet szolgáltatja:

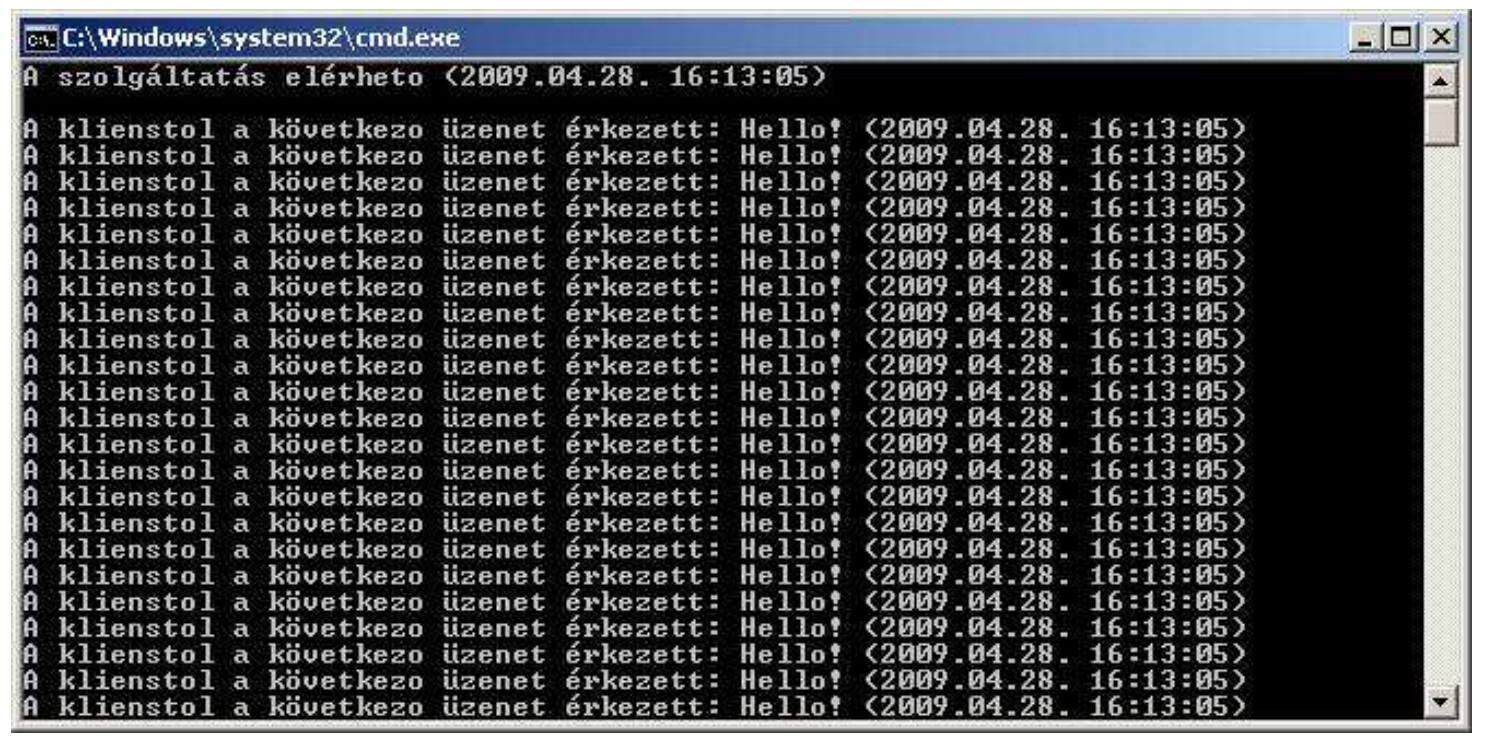

52. ábra - A szolgáltatás kimenete 
Látható, hogy a szolgáltatás körülbelül két órával az üzenetek küldése után indult el, de a kézbesítés sikeres volt. 


\section{3 Összefoglalás}

Diplomamunkám célja az volt, hogy ismertessem a Windows Communication Foundation szolgáltatások írásához nélkülözhetetlen fogalmakat, példákon keresztül bemutassan az általam fontosnak tartott technológiai lehetőségeket. A munkám és tanulmányaim során szerzett ismeretek, tapasztalatok alapján fontosnak tartottam, hogy beszámoljak a szinkron és aszinkron programozási modellről, a tranzakciós müködésről (erről egyetemi tanulmányaim során számos tárgy kapcsán tanultam), a munkamenetekről és nagy vonalakban az MSMQ-ról. Ezeket a célokat sikerült elérnem, azonban a diplomamunka készítése során szembesültem azzal, hogy a bevezetőben ismertetett tervezési célok megvalósításainak részletes tárgyalása már nem fér e dolgozat keretei közé, de a későbbiekben szeretnék ezzel komolyabban foglalkozni. 


\section{Köszönetnyilvánítás}

Szeretnék köszönetet nyilvánítani témavezetőmnek, Dr. Fazekas Gábor egyetemi docensnek a diplomamunkámat érintő hasznos tanácsokért, valamint a Debreceni Egyetem oktatóinak, akik munkájukkal hozzájárultak szakmai fejlődésemhez és tanulmányaim alatt segítségemre voltak, továbbá köszönettel tartozom Szeifert Péternének és Bölkény Edinának, hogy diplomamunkám írása során mindenben támogattak. 


\section{Irodalomjegyzék}

Chris Peiris, Dennis Mulder, Shawn Cicoria, Amit Bahree, Nishith Pathak: Pro WCF - Practical Microsoft SOA Implementation (2007)

Craig McMurtry, Marc Mercuri, Nigel Watling, Matt Winkler: Windows Communication Foundation Unleashed (2007)

Tony Northrup, Shawn Wildermuth, Bill Ryan : Microsoft .NET Framework 2.0 Application Development Foundation Training Kit (2006)

Glenn Johnson, Tony Northrup: Microsoft .NET Framework 2.0 Web-Based Client Development Training Kit (2007)

Andrew Troelsen: Pro C\# 2008 and the .NET 3.5 Platform, Fourth Edition (2007)

http://msdn.microsoft.com/hu-hu/library/ms735119(en-us).aspx

http://msdn.microsoft.com/hu-hu/library/bb400851(en-us).aspx

http://msdn.microsoft.com/hu-hu/library/aa139617\%28en-us\%29.aspx 